Fisheries Research

May 2018, Volume 206 Pages 14-26

http://dx.doi.org/10.1016/i.fishres.2018.04.019

http://archimer.ifremer.fr/doc/00439/55070/

(c) 2018 Published by Elsevier B.V. All rights reserved.

\title{
How do fishing practices influence sperm whale (Physeter macrocephalus) depredation on demersal longline fisheries?
}

\author{
Janc Anaïs ${ }^{1,{ }^{*}}$, Richard Gaétan ${ }^{1,2,3}$, Guinet Christophe ${ }^{1}$, Arnould John P.Y. ${ }^{3}$, \\ Villanueva Ching-Maria ${ }^{4}$, Duhamel Guy ${ }^{5}$, Gasco Nicolas ${ }^{5}$, Tixier Paul ${ }^{3}$
}

${ }^{1}$ Centre d'Études Biologiques de Chizé (CEBC), UMR 7273—CNRS and Université de La Rochelle, 79360 Villiers-en-Bois, France

${ }^{2}$ Lab-STICC UMR 6285, ENSTA Bretagne, 2 rue François Verny, 29806 Brest Cedex 9, France

${ }^{3}$ School of Life and Environmental Sciences (Burwood Campus), Deakin University, 221 Burwood

Highway, Burwood, VIC 3125, Australia

${ }^{4}$ Laboratoire de Biologie Halieutique (STH-LBH), IFREMER, ZI de la Pointe du Diable, BP 70, 29280

Plouzané, France

${ }^{5}$ Muséum National d'Histoire Naturelle, Département Adaptations du Vivant, UMR 7208 BOREA, CP

26, 43 rue Cuvier, 75005 Paris, France

* Corresponding author : Anaïs Janc, email address : anais.janc@cebc.cnrs.fr

gaetan.richard@cebc.cnrs.fr ; christophe.guinet@cebc.cnrs.fr ; john.arnould@deakin.edu.au ; ching.villanueva@ifremer.fr ; quy.duhamel@mnhn.fr ; nicolas.gasco@mnhn.fr ; p.tixier@deakin.edu.au

\begin{abstract}
:
Marine mammal depredation on fisheries (animals removing fish caught on fishing gear) is a worldwide issue involving socio-economic and ecological consequences. Longline fisheries are the most impacted by odontocete (toothed whales) depredation. While technological means have provided limited efficacy in reducing depredation, this study examined the fishing practices influencing both the proportion of depredated longline sets and the amount of fish removed by whales. We used an 8-year dataset from the Patagonian toothfish (Dissostichus eleginoides) longline fisheries operating in Crozet and Kerguelen Economic Exclusive Zones (EEZs) (South Indian Ocean) and GLMMs to investigate sperm whale (Physeter macrocephalus) depredation. Sperm whale depredation occurred on $61 \%$ of 5260 sets in Crozet and $41 \%$ of 16,902 sets in Kerguelen, and resulted in minimum estimated toothfish losses of 702 tons and 2649 tons, respectively, in the two areas. The probability of depredation decreased in winter months, increased with depth fished and decreased when vessels travelled over distances of $>60 \mathrm{~km}$ from fishing grounds with encountering depredation. These findings suggest the natural spatio-temporal distribution of sperm whales and their ability to follow vessels over limited ranges influence the number of captured fish removals. The amount of depredated toothfish decreased with the speed at which longline sets were hauled and increased with the soaking time of sets suggesting that whales may depredate sets during both hauling and soaking operations. Together, these observations indicate that rates of depredation may be influenced by the conditions of fishing operations and could therefore be
\end{abstract}


employed to implement strategies of avoidance in all fisheries facing similar depredation impacts.

Keywords : Depredation, Demersal longline, Sperm whale, Patagonian toothfish, Fishing practices 


\section{Introduction}

Human-wildlife conflicts, which often result from competition between animals and humans over the same resources, are as old as humankind (Anand and Radhakrishna, 2017; Treves et al., 2006; Woodroffe et al., 2005). In the marine environment, the global expansion of fisheries over the last fifty years has led to the overexploitation of many fish stocks and major changes in fishing techniques. It also has resulted to changes in food-search behavior of some predators such as marine mammals that has resulted in the emergence of direct marine predators-fisheries interactions, including depredation on fishing gears (Augé et al., 2012; Fertl, 2008; Kaschner and Pauly, 2004; Plagányi and Butterworth, 2002; Read, 2008). Depredation on fisheries is defined as the partial or total removal of captured fish from fishing equipment by marine predators (Donogue et al., 2002; Fertl, 2008; Read, 2005) and has received growing attention over the past five decades (Northridge, 1991). Marine mammals were reported as the taxa with the broadest range of depredating species. These species have been documented to depredate on a wide variety of fishing gears such as purse seines, trawls, gill nets, pots and baited longlines (Bearzi, 2002; Donogue et al., 2002; Fertl, 2008; Gales, 2003; Gilman et al., 2006; Hamer et al., 2012; Read, 2005; Werner et al., 2015).

Marine mammal depredation on fisheries often results in major socio-economic and ecological issues (Gilman et al., 2006). Economic issues for fisheries include both direct costs (i.e., catch losses) and indirect costs (i.e., additional fishing time, fuel consumption and payroll needed to complete fishing quotas, the implementation of strategies of marine mammals avoidance) (Maccarrone et al., 2014; Peterson et al., 2014). Ecological and conservation issues may include the overexploitation of the targeted fish resources (i.e., the amount of depredated fish are often not accounted for in fish stock assessments and quota allocation processes) and effects on the 
survival of marine mammal populations (e.g., increased risks of by-catch on fishing gear; lethal responses from illegal, unreported and unregulated fishers who may perceive these animals as competitors; habituation to an artificial foraging behavior; modification of energy balance; etc.) (Baird et al., 2002; Gasco et al., 2015; Gilman et al., 2007). For instance, artificial food provisioning from fisheries may increase prey availability for depredating predators, and was shown to positively influence the survival and reproduction of individuals in various populations (Oro et al., 2004; Tixier et al., 2015a, 2017; Ward et al., 2009). Together, these ecological consequences of marine mammal depredation were recently suggested as important to consider when managing fisheries, fish stocks and marine mammal populations through ecosystem-based approaches (Boyd, 2002; Guénette et al., 2006; Morissette et al., 2012; Trites et al., 1999; Williams et al., 2011).

Longline gear is a fishing device which is made up of a horizontal line, to which are attached droppers ending in baited hooks and takes fish by hooking (Brock, 1962). Longlining progressively emerged as the most selective fishing technique for large fish species during the 1980s and 1990s (Løkkeborg and Bjordal, 1992). Unlike other techniques, this fully exposes the hooked fish in the water column, making this catch easily accessible for depredating marine mammals (Fertl, 2008). Both pelagic and demersal longlining are subject to depredation worldwide (Forney et al., 2011; Mesnick et al., 2006; Muñoz-Lechuga et al., 2016; Passadore et al., 2015; Rabearisoa et al., 2012; Roche et al., 2007; Straley et al., 2006; Visser, 2000). While the issue on depredation remains sporadic in some fisheries, it has spread and substantially increased in others, jeopardizing their sustainability (Powell and Wells, 2011; Schakner et al., 2014) and raising a critical need for solutions to minimize or suppress it (Hamer et al., 2012).

Extensive efforts have been made by fishers and ship-owners to develop technological solutions to either deter marine mammals from fishing gear or to protect the fish caught on 
hooks. However, most trials of such devices have showed limited efficacy (Dyb, 2006a; Hamer et al., 2012; Mooney et al., 2009; O'Connell et al., 2015; Tixier et al., 2015b). The development of fishing strategies for avoiding interactions has provided more promising insights into ways to reduce depredation levels. For instance, increased knowledge of local marine mammal populations ecology has allowed some fisheries to target the timing or areas of low marine mammal presence and, thus, lower the probability of depredation (Guinet et al., 2015; Straley et al., 2015; Tixier, 2012; Tixier et al., 2016). Other studies have focused on the behavior of fishing vessels and operational factors that can be controlled. For instance, Tixier et al. (2015b) showed that the depth at which longlines are set, longline length, the hauling speed and the distance travelled by vessels between fishing grounds can significantly influence the proportion of fishing gear depredated by killer whales (Orcinus orca) and the impact of this depredation on the Catch Per Unit Effort (CPUE) of the target species.

The influence of such operational factors on sperm whale (Physeter macrocephalus) depredation, however, has remained poorly investigated despite several reports on significant depredation in the majority of longline fisheries operated in high latitudes (Mesnick et al., 2006; Taylor et al., 2008). In both hemispheres, demersal longline fisheries are primarily depredated by adult male sperm whales whose natural foraging grounds often overlap with fishing areas (Ashford et al., 1996; Best, 1979; Mesnick et al., 2006; Whitehead, 2003). Sperm whale depredation has been reported in the North Pacific on fisheries targeting Pacific halibut (Hippoglossus stenolepis) and sablefish (Anoplopoma fimbria) (Hill et al., 1999; Peterson and Carothers, 2013; Schakner et al., 2014; Sigler et al., 2008; Straley et al., 2006), in the North Atlantic on fisheries targeting Greenland halibut (Reinhardtius hippoglossoides) (Dyb, 2006b) and in the Southern Ocean on fisheries targeting Patagonian toothfish (Dissostichus eleginoides) (Duhamel, 2003). For the latter, sperm whale depredation occurs off Chile (Hucke-Gaete et al., 
2004; Moreno et al., 2008), the Falklands/Malvinas (Goetz et al., 2011; Nolan et al., 2000), South Georgia (Ashford et al., 1996; Moir Clark and Agnew, 2010; Purves et al., 2004; Söffker et al., 2015), Prince Edward Island (Kock et al., 2006; Tilney and Purves, 1999), Heard and McDonald Islands (Arangio, 2012) and Crozet and Kerguelen Islands (Ashford et al., 1996; Capdeville, 1997; Gasco et al., 2015; Roche et al., 2007; Tixier et al., 2010).

The Patagonian toothfish longline fishery operating off the Crozet and Kerguelen Islands has been reported as one of the most impacted by sperm whale depredation, with an estimated reduction of $8-12 \%$ in the toothfish CPUE between 2003 and 2013 (Gasco et al., 2015; Roche et al., 2007; Tixier et al., 2010). These estimates were recently incorporated in the Crozet and Kerguelen fish stock assessments and used to increase accuracy of quota allocation processes. This fishery, with a fleet comprised of seven commercial vessels, is highly regulated, closely monitored by onboard fishery observers at all times, and benefits from a long-term fishing dataset covering $100 \%$ of fishing operations. This fully controlled environment has proved to be particularly suitable for studies on operational factors influencing depredation by killer whales, the other major depredating species of demersal longline fisheries in high latitudes (Gasco, 2014; Guinet et al., 2015; Tixier et al., 2010; 2016).

Therefore, the long-term datasets from the Crozet and Kerguelen Patagonian toothfish fisheries were here used as a unique opportunity to investigate the spatio-temporal and operational factors of fishing practices influencing the level of sperm whale depredation on demersal longlining. The aims of this study were to test for the effects of these factors on (i) the proportion of fishing gear depredated by sperm whales, and (ii) the CPUE during sperm whale depredation events.

\section{Material and methods}




\subsection{Study areas and data collection}

During the study period (1 January, 2008-25 July, 2015), seven commercial fishing vessels were authorized to operate in the Crozet (between $44^{\circ}$ and $48^{\circ} \mathrm{S}-46^{\circ}$ and $54^{\circ} \mathrm{W}$ ) and Kerguelen (between $45^{\circ}$ and $52^{\circ} \mathrm{S}-63^{\circ}$ and $75^{\circ} \mathrm{W}$ ) Exclusive Economic Zones (EEZs). These vessels all used auto-weighted longlines that were set between two anchors at each end of the mainline, on which 375 - 47250 hooks were positioned with an individual hook every $1.2 \mathrm{~m}$. These hooks were automatically baited and dropped to the bottom at depths ranging from $500-2300 \mathrm{~m}$ (i.e., legal depth range to avoid the capture of juvenile toothfish; (Collins et al., 2010)). Fishing regulations also imposed fishers to set their lines at night to avoid seabird bycatch (Cherel et al., 1996; Weimerskirch et al., 2000). Hauling, which was allowed at any time of the day, took between 00:30 - 9:58 to be completed depending on the number of hooks on the longline and the hauling speed. The fishing fleet was allowed to operate all year round in the Crozet, but is closed for a 45-day period from the $1^{\text {st }}$ February to mid-March in the Kerguelen EEZ to comply with seabird conservation measures (CCAMLR, 2015a, 2015b).

All data used in the study were collected by fishery observers and were provided by the Muséum d'Histoire Naturelle de Paris (MNHN - PECHEKER database; (Martin and Pruvost, 2007)). The unit of this dataset was the longline set. Each set was affiliated with one captain, one vessel and one fishing trip. A fishing trip (lasting 2 - 3 months) was defined as the time between the departure of a vessel with a given captain from Reunion Island and its return to the port. The date, time, number of hooks set and hauled, spatial coordinates and depth of downlines at the beginning and the end of both setting and hauling processes were recorded for each longline set. The total number and the biomass of fish caught and landed for Patagonian toothfish was assessed as well as for three bycatch species groups (bigeye grenadier, Macrourus carinatus; blue antimora, Antimora rostrata and skate species grouped into a single group, Bathyraja 
eatonii, Bathyraja irrasa, Bathyraja murrayi for Kerguelen and Amblyraja taaf for Crozet). From these data, the CPUE was calculated as the biomass of entire caught fish in grams divided by the number of hauled hooks $\left(\mathrm{g} \cdot \mathrm{hook}^{-1}\right.$ ) for each hauled longline, for Patagonian toothfish and for each of the three bycatch species groups:

CPUE $_{\mathrm{i}}\left(\right.$ g.hook $\left.^{-1}\right)=\sum$ Biomass of entire caught fish i $_{\mathrm{i}} / \sum$ hauled hooks $_{\mathrm{i}}$ $C P U E_{\mathrm{i}}$ is the obtained CPUE on longline $i$

Concurrently, fishery observers visually monitored odontocetes (i.e., sperm whales and killer whales) depredating on longlines during hauling. Depredation was classified according to three states for each of the two depredating species: (i) "Depredation" - depredation of whales on the fishing gear was confirmed by whales repeating long dives (> $15 \mathrm{~min}$ ) within a $500 \mathrm{~m}$ radius from the vessel and surrounded by seabirds when surfacing, slicks of fish oil visible at the surface of the water and/or chunks of fish observed in the mouth of whales; (ii) "No depredation" - no whales sighted from the vessel or if sighted, whales were in transit with no indicators of depredation (see above) observed; (iii) "not observed" - observations were not possible due to weather, sea state and/or visibility conditions (e.g., night). For sets for which depredation was recorded during hauling, fishery observers provided minimum and maximum estimates of the number of whales present around the vessel. For the purposes of this study, and to limit bias due to overestimated numbers, only the minimum estimate was used to test the number of depredating sperm whales as an explanatory variable in the models presented below.

\subsection{Models on the proportion of fishing gear depredated by sperm whales}

Generalized Linear Mixed Models (GLMM) (Zuur et al., 2009, 2013) were used to explore the relationship between the proportion of hauled sets depredated by sperm whales out of all hauled sets (noted "Pr(set)") and three spatio-temporal predictors. Temporal predictors included a year 
("Year" - continuous) and a month ("Month" - discrete) effects to respectively test for annual trends and intra-annual variations of the proportion of sets depredated by sperm whales. The depth at which sets were hauled was considered here as the vertical spatial predictor ("Depth" continuous and expressed in meters). As observers recorded one depth value for each of the two ends of a set, we used the mean of these two values in the model. The continuous explanatory predictors were centered at their mean and scaled by their standard deviation (i.e., standardized). Data were restricted to longline sets with confirmed presence ("Depredation") or absence ("No depredation") of depredating sperm whales during hauling and fitted with a binomial distribution and a logit link function, which was defined as follows:

$\operatorname{logit}\left(\pi_{\mathrm{ij}}\right)=\eta_{\mathrm{ij}} \leftrightarrow \pi_{\mathrm{ij}}=\exp (\eta \mathrm{ij}) /(1+\exp (\eta \mathrm{ij}))$

in which $\pi_{\mathrm{ij}}$ represented the expected value of $\operatorname{Pr}($ set) for each longline $j$ in trip $i$ (i.e., the mean of $\left.\operatorname{Pr}(\text { set })_{\mathrm{ij}}\right)$ and $\operatorname{Pr}(\text { set })_{i j}$ took values of 0 or 1 for each longline $j$ in trip $i$.

The fishing trip ("Trip") was used as a random intercept to impose a correlation structure on the presence of depredating sperm whales because of multiple observations recorded for each trip (Zuur et al., 2013). The model was extended with a temporal auto-correlation structure to account for the fact that the interaction of sperm whales with a given longline set could depend upon their interaction with the previously hauled longline (Tixier, 2012). The full model (Model 1) was separately fitted on data from Crozet and Kerguelen using the function $g l m m P Q L$ in packages MASS (Venables and Ripley, 2002) and nlme (Pinheiro et al., 2016) in R (R Core Team, 2015) as follows:

Model 1: $\eta_{\mathrm{ij}}=$ Intercept $+\beta_{1}$ Year $+\beta_{2}$ Month $_{\mathrm{ij}}+\beta_{3}$ Dept $_{\mathrm{ij}}+a_{\mathrm{i}}+\varepsilon_{\mathrm{ij}}$

in which $a_{\mathrm{i}}$ and $\varepsilon_{\mathrm{ij}}$ were the residuals: $a_{\mathrm{i}} \sim N\left(0, \sigma^{2}\right.$ Trip $)$ and $\varepsilon_{\mathrm{ij}} \sim N\left(0, \sigma^{2}\right)$, and $\beta_{1,2,3}$ were the coefficients of the explanatory variables. 
Cleveland dot plots were used as an alternative to bar charts to inspect the outliers of variables. Collinearity between continuous variables was assessed using pair plots and variance inflation factor (VIF) values calculated as the ratio of variance in a model with multiple terms, divided by the variance of a model with one term alone (Zuur et al., 2009, 2010; Zuur, 2012). Model selection was performed by using backward stepwise selection, dropping the least significant interaction term from the model and refitting the model until terms were significant at 5\% level (Zuur et al., 2013).

Using the same modeling approach, a second GLMM was developed to investigate the effect of the distance travelled by fishing vessels from one hauled set depredated by sperm whales to the set hauled next in time. Previous studies have shown depredating odontocetes follow fishing vessels between fishing operations, sometimes over great distances (Tixier et al., 2015c). Preliminary analyses of photo-identification data collected in Crozet and Kerguelen suggested that sperm whales also follow vessels from one haul to the next, likely because vessels remain within the acoustical detection range of the whales (Thode et al., 2015). Fishing vessels travel at speeds ranging from 8 to 12 knots, which exceed the average swimming speed of sperm whales during travelling (1.5 - 3 knots; Aoki et al., 2007; Whitehead, 2003). Hence, increased distances between sets may result in vessels being able to outrun the depredating sperm whales which may eventually lose the acoustical detection of vessels. To test this assumption, $\operatorname{Pr}($ set $)$ was here fitted with data restricted to pairs of sets that were hauled successively in time (by the same fishing vessel during the same fishing trip) after the first set was hauled in presence of depredating sperm whales. Longlines hauled with in presence of killer whales, whether depredating alone or simultaneously with sperm whales, were not included in the analysis to limit the bias due to the effect of killer whale depredation on the distance travelled by fishing vessels. Assuming that there is a straight trajectory of the vessel between the two sets, the distance between pairs of sets 
("Distance" - continuous and expressed in kilometers) was calculated from the GPS coordinates of the mid-point between the two ends of the first set and the mid-point of the second set. The number of sperm whales recorded depredating on the previous set ("Nb.ind.set.l" - continuous) was also entered in the model and tested both as a single term and in interaction with Distance. We assumed that the greater Nb.ind.set.1, the more likely that at least one individual would be depredating again on the next set. As $99 \%$ of the values by $\mathrm{Nb}_{\text {.set }}$ - were comprised between 1 and 8 individuals, the dataset was restricted to 8 sperm whales recorded on the previous set to avoid bias due to extreme values while maintaining statistical power. The full model (Model 2) was also separately fitted on data from Crozet and Kerguelen with a binomial distribution and a logit link function as follows:

Model 2: $\eta_{\mathrm{ij}}=$ Intercept $+\beta_{1}$ Distance $_{\mathrm{ij}}+\beta_{2}$ Nb.ind. set ${ }_{-1 \mathrm{ij}}+\beta_{3}$ Distance $_{\mathrm{ij}} \mathrm{x}$ Nb. ind. set $_{-1 \mathrm{ij}}+$ $a_{\mathrm{i}}+\varepsilon_{\mathrm{ij}}$

in which $a_{\mathrm{i}}$ and $\varepsilon_{\mathrm{ij}}$ were residuals: $a_{\mathrm{i}} \sim N\left(0, \sigma^{2}\right.$ Trip $)$ and $\varepsilon_{\mathrm{ij}} \sim N\left(0, \sigma^{2}\right)$, and $\beta_{1,2,3}$ were the coefficients of the explanatory terms.

\subsection{Modelling the CPUE of longline sets}

As an exploratory analysis, and prior to modelling the CPUE, the fishing data on Patagonian toothfish and on bycatch were initially used to statistically identify which fish species were primarily removed by sperm whales from longline sets when depredating. Several t-test comparisons were performed on mean CPUEs of 4 groups of species caught on longlines (Patagonian toothfish and 3 bycatch groups: blue antimora, bigeye grenadier and skate species) between sets hauled without (absence of any odontocete species) and sets hauled in the presence of depredating sperm whales over the 2008-2015 period. Longlines hauled with in presence of 
killer whales were not included in the analysis to limit the bias due to the effect of killer whale depredation on the CPUE.

GLMMs were then developed to examine the relationship between the CPUE of the depredated fish species and 4 operational predictors depending on the number of sperm whales simultaneously depredating during hauling of a given set. This number ("Nb.ind") ranged from 0 for sets hauled in absence to 16 for Crozet and 15 individuals for Kerguelen. However, as 93\% of the values taken by this variable were comprised between 0 and 5 for Crozet and $94 \%$ were comprised between 0 and 4 for Kerguelen; the data used in models on the CPUE were restricted to a maximum number of 5 individuals for Crozet and 4 for Kerguelen to avoid bias due to extreme values while maintaining statistical power. Nb.ind was tested both as a single term because it was hypothesized that increasing Nb.ind negatively influenced on the CPUE of the depredated fish species. Nb.ind was also tested in interaction with the following operational predictors. First, we tested for the effect of the length of longline sets ("Length" - continuous and expressed in kilometers). Here, it was hypothesized that shorter sets, for which hauling time is reduced, may decrease the amount of depredated fish by sperm whales, usually approaching the longline after the hauling has started (Tixier et al., 2015c). Second, we tested for the effect of the hauling speed of sets ("HaulingSpeed" - continuous and expressed in number of hauled hooks per minute (hooks.min $\left.{ }^{-1}\right)$ ), which was calculated as the total number of hooks hauled on a given set divided by the total hauling time of that set. If sperm whales depredate on the catch only during hauling, we assumed that while reducing the time available for whales to access the catch, a simultaneous increase in hauling speed may also make the removal of captured fish from the sets more difficult for them (Tixier et al., 2015c). Third, we tested for the effect of the soaking time of sets ("SoakingTime" - continuous and expressed in hours), which was the time elapsed between the end of setting and the start of hauling. This variable was used to specifically 
investigate the possibility that sperm whales may also depredate on sets before hauling while the line is still at the bottom of the sea. If it is the case, shorter soaking time can also reduce the time available for whales to access the catch and, therefore, reduce the amount of depredated fish. Lastly, the effect of the depth at which sets were hauled ("Depth" - continuous and expressed in meters) was also entered in the models to account for bathymetric variations of fish abundance. The continuous predictors were centered at their mean and scaled by their standard deviation. The fishing trip (Trip) was then used as a random intercept. Using the function glmer in package lme4 (Bates et al., 2015) in R (R Core Team, 2015), models were fitted with a Gamma distribution and the logarithmic link function, which was defined as follows:

$\log \left(\mu_{\mathrm{ij}}\right)=\eta_{\mathrm{ij}} \leftrightarrow \mu_{\mathrm{ij}}=\exp \left(\eta_{\mathrm{ij}}\right)$

in which $\mu_{\mathrm{ij}}$ represented the expected value of CPUE of longline $j$ in trip $i$ (i.e., the mean of CPUE $\left._{\mathrm{ij}}\right)$.

The full model (Model 3) was separately fitted on data from Crozet and from Kerguelen as follows:

Model 3: $\eta_{\mathrm{ij}}=$ Intercept $+\beta_{1}$ Nb.ind $\mathrm{ij}_{\mathrm{ij}}+\beta_{2}$ Length $_{\mathrm{ij}}+\beta_{3}$ Depth $_{\mathrm{ij}}+\beta_{4}$ SoakingTime $_{\mathrm{ij}}+\beta_{5}$

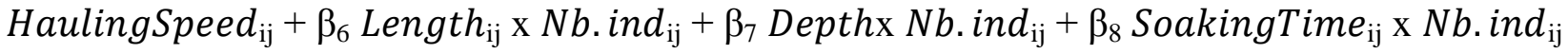
$+\beta_{9}$ HaulingSpeed $_{\mathrm{ij}} \times N b$. ind $_{\mathrm{ij}}+a_{\mathrm{i}}+\varepsilon_{\mathrm{ij}}$

in which $a_{\mathrm{i}}$ and $\varepsilon_{\mathrm{ij}}$ were residuals: $a_{\mathrm{i}} \sim N\left(0, \sigma^{2}\right.$ Trip $)$ and $\varepsilon_{\mathrm{ij}} \sim N\left(0, \sigma^{2}\right)$, and $\beta_{1,2,3,4,5,6,7,8,9 \text { were }}$ the coefficients of the explanatory terms.

Cleveland dot plots were also used to inspect the outliers of variables and collinearity between continuous variables was assessed using pair plots and VIF values (Zuur et al., 2009, 2010; Zuur, 2012). Model selection was performed using backward stepwise selection by dropping the least 
significant term interaction from the model and refitting the model until terms were significant at 5\% level (Zuur et al., 2013).

\section{Results}

\subsection{Data summary}

During the study, a total of 25715 longlines were set and hauled in both study areas: 6343 (25\%) in Crozet and 19372 (75\%) in Kerguelen. A total of 42688 tons of Patagonian toothfish were landed during the study with 5622 tons (13\%) in Crozet and 37066 (87\%) in Kerguelen. The absence or presence of depredating odontocetes was confirmed for $83 \%$ and $87 \%$ of all longline sets hauled in Crozet and Kerguelen, respectively. Sperm whales depredated on 60.5\% and $40.7 \%$ of these sets in Crozet and Kerguelen, respectively (Fig. 1).

In Crozet, $34.7 \% \pm 2.1 \% \mathrm{SE}$ of the sets were hauled in the presence of sperm whales as the only depredating species and $25.8 \% \pm 1.4 \%$ SE $(n=8$ years $)$ with sperm whales and killer whales depredating simultaneously. In Kerguelen, sets were primarily depredated by sperm whales alone at $40.6 \% \pm 1.1 \%$ SE while $0.1 \% \pm 0.05 \% \mathrm{SE}(\mathrm{n}=8$ years $)$ in presence of both sperm whales and killer whales. When depredation occurred, the average number of depredating sperm whales per set was significantly different between Crozet and Kerguelen (Student t-test: $t=-16.87, d f=$ $10038, P<0.001)$ and was estimated at $3.5 \pm 2.9 \mathrm{SD}$ individuals per set in Crozet $(\mathrm{n}=3188$ sets $)$ and 2.6 \pm 1.9 SD individuals per set in Kerguelen $(n=6852$ sets). The average number of depredating sperm whales per set varied between months in both areas. In Crozet, it was the highest in December (5.31 \pm 4.02 SD) and the lowest in September (1.89 $\pm 1.15 \mathrm{SD}$, Fig. 2a). In Kerguelen, it was the highest in April $(3.17 \pm 2.40 \mathrm{SD})$ and the lowest in July $(2.00 \pm 1.01 \mathrm{SD}$, Fig. 2a). 


\subsection{Models on the proportion of fishing gear depredated by sperm whales}

Results from Model 1 indicated in Table 1 showed that no significant annual trend in the proportions of sets depredated by sperm whales from 2008 to 2015 was observed in either area. However, significant inter-month variations were detected. Predicted probabilities of sperm whale depredation from the model were the highest between November (0.75 [95\% CI: $0.65-$ 0.83]) and January (0.85 [95\% CI: $0.78-0.90])$ in Crozet and between November (0.62 [95\% CI: 0.55 - 0.69]) and December (0.65 [95\% CI: 0.59 - 0.71]) in Kerguelen (Fig. 2b). These probabilities were the lowest between July $(0.48$ [95\% CI: $0.34-0.63])$ and October (0.44 [95\% CI: $0.35-0.54])$ in Crozet and between April (0.27 [95\% CI: $0.22-0.33])$ and July (0.06 [95\% CI: $0.03-0.11]$ ) in Kerguelen (Fig. 2b).

The depth at which longlines were set had no effect on the proportion of depredated sets in Crozet (Table 1). However, the depth effect was significant and positive in Kerguelen $(t=7.94$, $d f=16559, P=0.00$ ). For a typical trip in Kerguelen, the probability of sperm whale depredation increased from 0.30 [95\% CI: $0.09-0.50$ ] for sets hauled $506 \mathrm{~m}$ deep to 0.48 [95\% CI: $0.27-0.70$ ] for sets hauled $2140 \mathrm{~m}$ deep.

Results from Model 2 indicated in Table 2 showed that the number of depredating sperm whales recorded during the hauling of the first longline had a significant and positive effect on the proportion of subsequent sets hauled with depredation, both in Crozet $(z=4.04, P<0.001)$ and in Kerguelen $(z=12.18, P<0.001)$. In the same case, the distance travelled by vessels between the two sets had a significant and negative effect on the proportion of the next sets depredated by sperm whales, both in Crozet $(z=-9.62, P<0.001)$ and in Kerguelen $(z=-14.74$, $P<0.001)$. The interaction term between the variables Distance and $N b$.ind.set. 1 was significant and negative both in Crozet $(z=-2.40, P=0.02)$ and in Kerguelen $(z=-5.26, P<0.001)$. From the model outputs, the effect of the number of depredating sperm whales during hauling of the 
first set on the proportion of next sets depredated became negligible if vessels travelled more than $55.8 \mathrm{~km}$ in Crozet and $48.6 \mathrm{~km}$ in Kerguelen (Fig. 3). Based on an average number of sperm whales depredating on the first set, the estimated probabilities of the next sets to be depredated in Crozet was decreased by $10.7 \%$ when vessels travelled $20 \mathrm{~km}$ from the previous set, and by $39.8 \%$ when vessels travelled $50 \mathrm{~km}$. This rate was greater in Kerguelen. The probability of the next sets to be depredated was decreased by $15.9 \%$ when vessels travelled $20 \mathrm{~km}$ from the previous set and by $65.2 \%$ when vessels travelled $50 \mathrm{~km}$ (Fig. 3).

\subsection{Modelling the CPUE of longline sets}

A significant decrease of CPUE of Patagonian toothfish between non-depredated and depredated longline sets by sperm whales was detected both at Crozet (Student t-test: $t=-3.07, d f$ $=402, P=0.002$ ) and at Kerguelen (Student t-test: $t=-4.58, d f=1194, P<0.001$ ) while no effect could be detected on monitored bycatch species (Fig. 4).

Results from Model 3, which was therefore run on Patagonian toothfish CPUE, indicated in Table 3 showed that the number of depredating sperm whales per set had a significant and negative effect on toothfish CPUE for both study areas $(t=-8.56, P<0.001$ for Crozet and $t=-$ 14.09, $P<0.001$ for Kerguelen). From the model output, the CPUE loss was estimated at 24.72 g.hook ${ }^{-1}$ in Crozet and 17.65 g.hook $^{-1}$ in Kerguelen per sperm whale individual (see Supplementary Data for details on calculations). For both areas, the interaction term between the number of sperm whales interacting $N b$.ind and the variable Length or the variable Depth had no significant effect on toothfish CPUE.

The soaking time had no effect on toothfish CPUE in absence of cetaceans in Crozet $(t=0.91$, $P=0.36)$ whereas it had a significantly positive effect in Kerguelen $(t=9.83, P<0.001)$. The interaction term between the number of sperm whales and the variable SoakingTime had no 
significant effect on toothfish CPUE in Kerguelen. However, this interaction term was significant and had a negative effect on toothfish CPUE in Crozet $(t=-1.97, P=0.05)$. For instance, soaking times of 10 and $60 \mathrm{~h}$, respectively, resulted in toothfish CPUEs of 169.68 and 168.27 g.hook ${ }^{-1}$ (e.g., CPUE reduction of $0.8 \%$ ) when two sperm whales simultaneously depredated on a given set. CPUEs further decreased to values of 134.94 and 105.45 g.hook $^{-1}$ (e.g., CPUE reduction of 21.9\%) when five sperm whales simultaneously depredated on a given set (Fig. 5).

The hauling speed had a significant negative effect on toothfish CPUE in the absence of cetaceans both at Crozet $(t=-3.74, P<0.001)$ and at Kerguelen $(t=-16.16, P<0.001)$. In interaction with the number of sperm whales, the hauling speed had no significant effect on the toothfish CPUE in Crozet, but the effect was significant and positive in Kerguelen $(t=3.54, P<$ 0.001). For instance, the presence of 1 and 4 depredating whales on a given set resulted in

toothfish CPUEs of 288.50 and 229.69 g.hook $^{-1}$ (e.g., CPUE reduction of 20.4\%), respectively, when using a hauling speed of 20 hooks. $\mathrm{min}^{-1}$. A further decrease was observed at 199.48 and 185.07 g.hook $^{-1}$ (e.g., CPUE reduction of $\left.7.2 \%\right)$ when a hauling speed of 50 hooks.min ${ }^{-1}$ was used (Fig. 6). The model also estimated that the effect of the number of sperm whales on the amount of depredated toothfish became negligible for speeds greater than 60 hooks.min ${ }^{-1}$ (Fig. 6).

\section{Discussion}

This study provided evidence that sperm whales specifically remove Patagonian toothfish from longlines when depredating on fisheries of the Crozet and Kerguelen EEZs. This depredation varied in space and time and was influenced by a number of operational variables. The proportion of depredated sets depended upon the season and the depth at which longlines were set and was influenced by the distance travelled by vessels when switching from one fishing ground to another while trying to avoid depredation. This study also demonstrated that the 
amount of Patagonian toothfish depredated by sperm whales varied with (1) the number of individuals co-occurring around the vessels, (2) the speed at which longline sets were hauled, and (3) the soaking time of sets. These findings provide interesting insights to the understanding of factors that may influence and mitigate sperm whale depredation on the studied fisheries, as well as for other longline fisheries facing similar sperm whale interactions.

\subsection{Sperm whale depredation levels}

The proportions of longline sets hauled in presence of depredating sperm whales in Crozet (61\%) and Kerguelen (41\%) are among the highest ever recorded in the Southern Ocean region and in other demersal longline fisheries experiencing depredation. For example, sperm whales have been reported depredating on 18 to $25 \%$ of Patagonian toothfish longline sets in South Georgia (Moir Clark and Agnew, 2010; Purves et al., 2004; Söffker et al., 2015) and 35\% of the sets in the Falklands (Goetz et al., 2011; Yates and Brickle, 2007). In Alaska, 10 to 35\% of all longline sets were depredated by sperm whales on the sablefish fisheries (Hill et al., 1999; O’Connell et al., 2015; Peterson and Carothers, 2013; Straley et al., 2006, 2015; Thode et al., 2015).

The proportions of sets depredated by sperm whale reported here, which were calculated over the 2008-2015 period, are consistent with estimates from other studies including years preceding the study period considered in this work (Gasco et al., 2015; Roche et al., 2007; Tixier et al., 2010). In addition, no annual trend in the proportion of depredated sets was detected in this study. Together, these results suggest that the proportion of fishing gear depredated by sperm whales in Crozet and Kerguelen remains relatively constant over a period of nearly 13 years.

While sperm whales may naturally forage on other prey items such as large cephalopods that are not caught on longlines (Clarke and MacLeod, 1974; Kawakami, 1980), Patagonian toothfish 
has been observed as being part of their natural diet (Abe and Iwami, 1989; Duhamel et al., 2005; Gon and Heemstra, 1990; Yukhov, 1972, 1982). During depredation events, sperm whales primarily removed Patagonian toothfish from longlines despite the presence of other species caught as by-catch. Greater numbers of toothfish on longline sets and its larger size compared to bycatch species may respectively increase the probability of sperm whales to encounter toothfish and facilitate its detection during depredation events, which may therefore contribute to this selectivity. However, the latter is more likely to be explained by the optimal energetic intake sperm whales may gain when feeding on this fish species, which energetic richness is higher than that of other fish species caught on longlines (Capdeville, 1997; Collins et al., 2010; Duhamel, 2003; Fertl, 2008; Péron et al., 2016). As selective depredation towards Patagonian toothfish was also reported for killer whales in Crozet (Tixier et al., 2016), interspecific competition for the same resource can also likely occur when two odontocete species simultaneously depredate on the same longline sets.

Decreases in Patagonian toothfish CPUE caused by sperm whale depredation were detected both in Crozet and Kerguelen (i.e., 24.72 g.hook $^{-1}$ and 17.65 g.hook $^{-1}$ per sperm whale individual, respectively). If multiplied by the number of hooks hauled and the number of individuals for each of the longline sets hauled in presence of sperm whales as the only depredating species, such declines in toothfish CPUE resulted in estimated total losses of 702 tons in Crozet and 2649 tons in Kerguelen for the period of 2008-2015. However, the extent of this CPUE decrease is likely to be underestimated. First, as the distribution of sperm whales is often correlated with highly productive fishing grounds (Gasco et al., 2015; Goetz et al., 2011; Hucke-Gaete et al., 2004; Purves et al., 2004; Tixier, 2012), simple comparisons between the CPUE of all sets hauled in the absence and in the presence of depredating sperm whales are likely to be biased upward. Second, visual monitoring may lead to some depredation events being missed and unrecorded. The diving 
behaviour and capabilities of sperm whales (Jaquet, 1996; Watkins et al., 1985) which allow them to interact with longline sets at greater depths, may result in individuals remaining at great distances from the vessels and for longer period of time underwater.

\subsection{Spatio-temporal variations in the proportion of sets depredated}

For both Crozet and Kerguelen, the models developed on the proportion of depredated sets indicated that sperm whales were significantly less likely to depredate on fishing gear in winter months. This result was also reported in previous studies (Labadie et al., 2018; Tixier, 2012), and was attributed to the male sperm whale migration patterns of moving between feeding grounds in cold waters and reproduction grounds in tropical and sub-tropical waters (Jaquet et al., 2000; Madsen et al., 2002; Mellinger et al., 2004; Teloni et al., 2008).

The amplitude in the likelihood of sperm whale-fishery interaction between winter and summer months was lower in Crozet than in Kerguelen. However, variations in the mean number of sperm whales simultaneously depredating the same set were greater in Crozet than in Kerguelen, with increased numbers in summer months in Crozet. These differences may be explained by the size of the fishing area being smaller and the density of depredating sperm whales being greater in Crozet than in Kerguelen. The size of the Crozet fishing area is 20512 $\mathrm{km}^{2}$, a third of the Kerguelen fishing area $\left(63200 \mathrm{~km}^{2}\right)$. From Labadie et al. (2018), the annual number of depredating sperm whales was estimated to 82 in Crozet and 106 in Kerguelen, which, if divided by the size of the fishing areas, resulted in 0.0040 sperm whale per $\mathrm{km}^{-2}$ in Crozet, and 0.0017 sperm whale per $\mathrm{km}^{-2}$ in Kerguelen. As a result, the likelihood of vessels to be detected and depredated may remain higher in Crozet than in Kerguelen.

Restricting the fishing activity to winter months is likely to minimize the rate of interaction of sperm whales with vessels, and therefore the amount of depredated toothfish. A possible evidence 
of such application is the extremely low proportion of sets depredated by sperm whales in the Australian Patagonian toothfish longline fishery operating around Heard and MacDonald Island (HIMI), at the Southern border of the Kerguelen EEZ. Unlike the Kerguelen longlining, which operates all year round, HIMI demersal longlining has been restricted to the April-November period. In the latter, the rate of depredation by sperm whales has remained lower than $5 \%$ ever since (CCAMLR, 2015c). However, this low depredation rate may also be explained by sperm whale densities being naturally low at the latitudes of HIMI fishing grounds and/or by the fact that trawling has been the primary fishing technique used in this area until longlining emerged in recent years.

Different sizes in fishing areas may also explain the fact that the depth at which longlines were set influenced the proportion of sets depredated in Kerguelen but not in Crozet. Paired with higher densities of depredating individuals and steeper bathymetric slopes, vessels are more likely to be detected and reached more quickly by sperm whales in the small fishing areas of Crozet than in Kerguelen. As such, the spatial variations in the proportion of sets depredated may better reflect the natural distribution of sperm whales in Kerguelen. Increased probability of depredation on sets hauled at greater depths may indicate that sperm whales are naturally distributed at the outer edge of the Kerguelen oceanic shelf, which corresponds to the type of feeding ground preferentially used by other males in other high latitude areas (Whitehead, 2003).

\subsection{Operational means to mitigate sperm whale depredation}

When leaving a given fishing ground where sperm whale depredation occurred, vessels were significantly less likely to have their next longline sets depredated if they travelled over large distances, on average greater than $60 \mathrm{~km}$ (i.e., 32 nautical miles) because sperm whales may lose acoustical detection of vessels (G. Richard, pers. comm.). While further analysis would be 
required at the individual level using photo-identification, this result indicate that sperm whales do not follow fishing vessels over large distances and could be used as a mitigation measure to reduce depredation. From previous studies, implementing a "move-on" technique may be an effective strategy to avoid odontocete depredation (Peterson and Carothers, 2013; Tixier et al., 2015c). However, as indicated by a lower distance effect on sperm whale depredation in Crozet than in Kerguelen, this strategy may be highly dependent upon the size of the fishing areas and the densities of sperm whales as we explained in the previous section.

In Crozet, the hauling speed had no effect on sperm whale depredation but increased soaking time of longline sets at the bottom combined with increased number of depredating sperm whales present around the vessel resulted in lower toothfish CPUE. Together, these results suggest that sperm whales may also depredate toothfish caught on longline sets before hauling. While this assumption remains poorly investigated, preliminary acceleration/acoustic data indicated that sperm whales were already present in the vicinity of the fishing gear prior to hauling and may interact with longlines at the bottom (A. Janc and G. Richard, pers. comm.). Sperm whales are deep diving animals and their diving range does overlap with the depths at which longlines are set (Fiscus, 1982; Jaquet et al., 2000; Jaquet and Gendron, 2002). As depredation can also occur when sets are soaked, depredation events can be missed, and therefore underestimated, if this process is only monitored visually from vessels during hauling operations.

In Kerguelen, the soaking time of sets had no effect on sperm whale depredation but the increased hauling speed was found to decrease sperm whale depredation. The extent of this correlation increased with increasing number of sperm whales simultaneously depredating on longline sets during hauling. Leaving toothfish caught on hooks in the water column for a shorter amount of time may prevent the whales from removing large proportions of toothfish. As a large body size reduces its maneuverability (Dial et al., 2008), a faster moving line may also make 
depredation more difficult for sperm whales. This assumption is supported by a lower hauling speed threshold above which CPUE remained unchanged for sperm whales (60 hooks. $\min ^{-1}-$ this study) than for killer whales (80 hooks. $\mathrm{min}^{-1}$ - Tixier et al., 2015c).

Hauling speed and soaking time had different effects on sperm whale depredation depending on whether vessels operated in Crozet or Kerguelen. The influence of the soaking time detected in Crozet only suggests that sperm whales are more likely to depredate during soaking in this area than in Kerguelen. This difference can be interpreted by higher densities of sperm whales paired with high depredation by killer whales in Crozet (Gasco et al., 2015; Guinet et al., 2015; Tixier, 2012; Tixier et al., 2010, 2016), which are likely to increase both inter- and intra-specific competition for toothfish caught on longlines. Depredation on sets on the seafloor, which may be more energetically costly than depredation at shallow depths during hauling, may be a response of sperm whales to competition when the number of depredating odontocetes increases around vessels.

\subsection{Conclusions}

Together, the findings of this study could be used to develop operational fishing strategies that minimize odontocete depredation on longline fisheries of the Southern Ocean region. Targeting fishing periods of low depredating sperm whales presence, paired with other factors such as an increase in distance travelled between fishing grounds, an optimal depth at which longlines are set, a shorter soaking time at the bottom and a faster speed at which hooks are hauled may work as easy-to-implement mitigation measures to avoid or mitigate response to depredation. However, as these strategies may induce additional constraints for fishers (Maccarrone et al., 2014; Peterson et al., 2014), full bio-socio-economic assessments of the costs and benefits of changing fishing practices would be needed. For instance, the "move-on" technique may involve increased non-fishing time and motor-fuel consumption that can render this fishing strategy less 
advantageous to fishers or sustainable to the fishery itself. To increase profitability, these additional costs should not exceed the benefits gained by minimizing depredation (Trijoulet, 2016; Trijoulet et al., 2018). Further assessments are also be needed to ensure that these operational adaptive measures are in agreement with fisheries regulations and resource management strategies, which is currently one of the key challenges for various stakeholders (Doyen et al., 2017, 2012; Gourguet et al., 2013; Nielsen et al., 2018). This study has also emphasized the various gaps of knowledge on odontocete depredation. For instance, sperm whales interaction with the fishing gear, and more importantly, the possible occurrence of depredation when lines are still fishing before hauling. These may have direct implications on various aspects of the issue, including toothfish stock management, whale population conservation, and the ecosystem stability. Such information can also provide knowledge on other possible technical means and opportunities that can reduce depredation, such as the use of toothfish protecting devices which are currently receiving a growing attention and may be further developed in the future.

\section{Funding}

The first author was financially supported by a departmental funding allocated directly by the Ministère de l'Éducation Nationale, de l'Enseignement Supérieur et de la Recherche (M.E.N.E.S.R) via the campaign doctoral contracts handicap 2015 (Contract $\mathrm{n}^{\circ}$ 2015-5286).

\section{Acknowledgements}

This work could not have been possible without the intensive and rigorous contribution of all the fishery observers and fieldworkers from the French fishing vessels collecting the data. We thank the Terres Australes et Antarctiques Françaises (TAAF) and the Réserve Naturelle 
Nationale des TAAF for supporting the work of the fishery observers. We are also very grateful to the Muséum National d'Histoire Naturelle de Paris for undertaking the scientific monitoring and fieldwork. Special thanks to P. Pruvost, A. Martin and C. Chazeau for providing some of the data from the "PECHEKER" database supported by the Ministère de l'Agriculture et de l'Alimentation (Direction des Pêches Maritimes et de l'Aquaculture). The long-term monitoring of killer whales and sperm whales was supported by program 109, headed by H. Weimerskirch of the French Polar Institute. This work is a part of the OrcaDepred project leaded by C. Guinet and financed by the Agence National de la Recherche (ANR), the French Ministry of Environment, the Fondation d'Entreprises des Mers Australes and the Syndicat des Armements Réunionnais des Palangriers Congélateurs (SARPC). Special thanks are due to B. Le Gallic and S. Gourguet for their insights on the manuscript. We are thankful to the reviewers for their relevant comments to improve the paper.

\section{Author Contributions}

Study conception and design: AJ CG PT

Acquisition of data: AJ CG PT

Analysis and interpretation of data: AJ GR PT

Drafting of manuscript: AJ GR CG JA MCV GD NG PT

Critical revision: AJ GR PT

\section{References}

Abe, T., Iwami, T., 1989. Notes on fishes from the stomachs of whales taken in the Antarctic. II. On Dissostichus and Ceratias, with an appendix (Japanese names of important Antarctic fishes). Proc. NIPR Symp. Polar Biol. 2, 78-82.

http://ci.nii.ac.jp/els/contentscinii_20171022023320.pdf?id=ART0000356115 
Anand, S., Radhakrishna, S., 2017. Investigating trends in human-wildlife conflict: is conflict escalation real or imagined? J. Asia-Pac. Biodivers. 10, 154-161. https://doi.org/10.1016/j.japb.2017.02.003

Aoki, K., Amano, M., Sugiyama, N., Muramoto, H., Suzuki, M., Yoshioka, M., Mori, K., Tokuda, D., Miyazaki, N., 2007. Measurement of swimming speed in sperm whales. IEEE, pp. 467-471. https://doi.org/10.1109/UT.2007.370754

Arangio, R., 2012. Minimising whale depredation on longline fishing Australian toothfish fisheries. Report Nuffield Australia Project. 43 pp. http://www.nuffieldinternational.org/rep_pdf/1353965947Rhys_Arangio_final_report.pdf

Ashford, J.R., Rubilar, P.S., Martin, A.R., 1996. Interactions between cetaceans and longline fishery operations around South Georgia. Mar. Mammal Sci. 12(3), 452-457. http://onlinelibrary.wiley.com/doi/10.1111/j.1748-7692.1996.tb00598.x/abstract

Augé, A.A., Moore, A.B., Chilvers, B.L., 2012. Predicting interactions between recolonising marine mammals and fisheries: defining precautionary management. Fish. Manag. Ecol. 19, 426-433. https://doi.org/10.1111/j.1365-2400.2012.00861.x

Baird, R.W., Stacey, P.J., Duffus, D.A., Langelier, K.M., 2002. An evaluation of gray whale (Eschrichtius robustus) mortality incidental to fishing operations in British Columbia, Canada. J. Cetacean Res. Manag. 4(3), 289-296. http://citeseerx.ist.psu.edu/viewdoc/download?doi=10.1.1.503.7596\&rep=rep1\&type=pdf

Bates, D., Mächler, M., Bolker, B., Walker, S., 2015. Fitting Linear Mixed-Effects Models Using lme4. J. Stat. Softw. 67(1), 1-48. https://doi.org/10.18637/jss.v067.i01

Bearzi G. 2002. Interactions between cetacean and fisheries in the Mediterranean Sea. In: G. Notarbartolo di Sciara (Ed.), Cetaceans of the Mediterranean and Black Seas: state of knowledge and conservation strategies. A report to the ACCOBAMS Secretariat, Monaco, February 2002. Section 4 , $20 \quad$ pp. http://www.dolphinbiology.org/_download/literature/Bearzi_2002.pdf

Best, P.B., 1979. Social organization in sperm whales, Physeter macrocephalus, in: Behavior of Marine Animals. Springer, pp. 227-289.

Boyd, I.L., 2002. Integrated environment-prey-predator interactions off South Georgia: implications for management of fisheries. Aquat. Conserv. Mar. Freshw. Ecosyst. 12(1), 119-126. https://doi.org/10.1002/aqc.481

Brock, V.E., 1962. On the nature of the selective fishing action of longline gear. Pac. Sci. 16(1), $3-14$.

http://scholarspace.manoa.hawaii.edu/bitstream/10125/5972/1/vol16n1-3-14.pdf

Capdeville, D., 1997. Interaction of marine mammals with the longline fishery around the Kerguelen Islands (Division 58.5. 1) during the 1995/96 cruise. CCAMLR Sci. 4, 171174. https://www.ccamlr.org/en/system/files/science_journal_papers/12capdeville.pdf

CCAMLR, 2015a. Fishery report 2015: Dissostichus eleginoides Crozet Island French EEZ (Subarea 58.6). https://www.ccamlr.org/en/system/files/06\%20TOP586\%202015_0.pdf

CCAMLR, 2015b. Fishery Report 2013: Dissostichus eleginoides Kerguelen Islands French EEZ (Division 58.5.1). https://www.ccamlr.org/fr/system/files/05\%20TOP5851.pdf

CCAMLR, 2015c. Spatial and temporal patterns of sperm whale (Physeter macrocephalus) depredation on Australian longline vessels in the Patagonian toothfish (Dissostichus eleginoides) fishery at Heard Island and McDonald Islands (CCAMLR Division 58.5.2). 
Cherel, Y., Weimerskirch, H., Duhamel, G., 1996. Interactions between longline vessels and seabirds in Kerguelen waters and a method to reduce seabird mortality. Biol. Conserv. 75, 63-70.

https://s3.amazonaws.com/academia.edu.documents/45406025/Interactions_between_lon gline_vessels_an20160506-26748-

d0gc79.pdf?AWSAccessKeyId=AKIAIWOWYYGZ2Y53UL3A\&Expires $=1508687150$ $\&$ Signature $=\mathrm{eNiEE} 1 \mathrm{MtM}$ 5pC6onTXbXhAM4f1hk\%3D\&response-contentdisposition=inline\%3B\%20filename\%3DInteractions_between_longline_vessels_an.pdf

Clarke, M.R., MacLeod, N., 1974. Cephalopod remains from a sperm whale caught off Vigo, Spain. J. Mar. Biol. Assoc. U. K. 54, 959-968.

Collins, M.A., Brickle, P., Brown, J., Belchier, M., 2010. The Patagonian toothfish: biology, ecology and fishery. Adv. Mar. Biol. 58, 227-300.

Dial, K.P., Greene, E., Irschick, D.J., 2008. Allometry of behavior. Trends Ecol. Evol. 23(7), 394-401. https://doi.org/10.1016/j.tree.2008.03.005

Donogue, M., Reeves, R.R., Stone, G.S., 2002. Report of the workshop on interactions between cetaceans and longline fisheries. http://www.nmfs.noaa.gov/pr/pdfs/interactions/samoa2002.pdf

Doyen, L., Thébaud, O., Béné, C., Martinet, V., Gourguet, S., Bertignac, M., Fifas, S., Blanchard, F., 2012. A stochastic viability approach to ecosystem-based fisheries management. Ecol. Econ. 75, 32-42. https://doi.org/10.1016/j.ecolecon.2012.01.005

Doyen, L., Béné, C., Bertignac, M., Blanchard, F., Cissé, A.A., Dichmont, C., Gourguet, S., Guyader, O., Hardy, P.-Y., Jennings, S., 2017. Ecoviability for ecosystem-based fisheries management. Fish Fish. 18(6), 1056-1072.

http://faere.fr/pub/Conf2015/Doyen_FAERE2015_ecoviability.pdf

Duhamel, G., 2003. La légine, pêcherie conflictuelle. Pêche légale et braconnage organisé. Cas $\mathrm{du}$ secteur indien de l'océan Austral. https://www.researchgate.net/publication/292993830_La_legine_pecherie_conflictuelle_P eche_legale_et_braconnage_organise_Cas_du_secteur_indien_de_1\%27ocean_Austral

Duhamel, G., Gasco, N., Davaine, P., 2005. Poissons des îles Kerguelen et Crozet (guide régional de l'océan Austral), Patrimoines naturels.

Dyb, J.E., 2006a. Experiences of the Norwegian longline fleet with "pingers" and "scramblers.", in: Symposium on fisheries depredation by killer and sperm whales: Behavioural insights, behavioural solutions. http://www.vanaqua.org/depredation/Documents/JanErikExtendedAbstractpingersandscramblers.kh.pdf

Dyb, J.E., 2006b. Fisheries depredation experience of the Norwegian longline fleet, in: Symposium on fisheries depredation by killer and sperm whales: Behavioural insights, behavioural solutions. http://www.vanaqua.org/depredation/Documents/JanErikExtendedAbstractNorwegianlonglinefleet.kh.pdf

Fertl, D., 2008. Fisheries, interference with. ResearchGate 439-443. https://doi.org/10.1016/B978-0-12-373553-9.00104-8

Fiscus, C.H., 1982. Predation by marine mammals on squids of the Eastern North Pacific Ocean and the Bering Sea. Mar. Fish. Rev. 44(2), 1-10. http://oceanrep.geomar.de/34031/1/761.pdf

Forney, K.A., Kobayashi, D.R., Johnston, D.W., Marchetti, J.A., Marsik, M.G., 2011. What's the catch? Patterns of cetacean bycatch and depredation in Hawaii-based pelagic longline fisheries. Mar. Ecol. 32, 380-391. 
Gales, N., 2003. Marine mammals: fisheries, tourism and management issues. CSIRO, Collingwood, Vic.

Gasco, N., Tixier, P., Guinet, C., Duhamel, G., 2014. Déprédation de la légine (Dissostichus eleginoides) par les orques (Orcinus orca), les cachalots (Physeter macrocephalus) et les otaries (Arctocephalus spp.) à Kerguelen et Crozet (Océan indien sud). Conséquences sur la gestion de la pêcherie et évaluation de solutions. Diplôme de l'École Pratique des Hautes Études. 92 pp.

Gasco, N., Tixier, P., Duhamel, G., Guinet, C., 2015. Comparison of two methods to assess fish losses due to depredation by killer whales and sperm whales on demersal longlines. CCAMLR Sci. 22, 1-14.

https://www.researchgate.net/profile/Guy_Duhamel/publication/283436631_Comparison _of_two_methods_to_assess_fish_losses_due_to_depredation_by_killer_whales_and_spe rm_whales_on_demersal_longline/links/56e669b908ae98445c2211ea.pdf

Gilman, E., Brothers, N., McPherson, G., Dalzell, P., 2007. A review of cetacean interactions with longline gear. J. Cetacean Res. Manag. 8(2), 215-223.

https://www.researchgate.net/profile/Eric_Gilman2/publication/233961862_Review_of_c etacean_interactions_with_longline_gear/links/0912f50d67d6e476b7000000.pdf

Goetz, S., Laporta, M., Martinez Portela, J., Santos, M.B., Pierce, G.J., 2011. Experimental fishing with an "umbrella-and-stones" system to reduce interactions of sperm whales (Physeter macrocephalus) and seabirds with bottom-set longlines for Patagonian toothfish (Dissostichus eleginoides) in the Southwest Atlantic. ICES J. Mar. Sci. 68(1), 228-238. https://doi.org/10.1093/icesjms/fsq161

Gon, O., Heemstra, P.C., 1990. Fishes of the Southern Ocean, J.L.B. Smith Institute of Ichthyology, Grahamstown. 462 pp.

Gourguet, S., Macher, C., Doyen, L., Thébaud, O., Bertignac, M., Guyader, O., 2013. Managing mixed fisheries for bio-economic viability. Fish. Res. 140, 46-62. https://doi.org/10.1016/j.fishres.2012.12.005

Guénette, S., Heymans, S.J., Christensen, V., Trites, A.W., 2006. Ecosystem models show combined effects of fishing, predation, competition, and ocean productivity on Steller sea lions (Eumetopias jubatus) in Alaska. Can. J. Fish. Aquat. Sci. 63(11), 2495-2517. https://doi.org/10.1139/f06-136

Guinet, C., Tixier, P., Gasco, N., Duhamel, G., 2015. Long-term studies of Crozet Island killer whales are fundamental to understanding the economic and demographic consequences of their depredation behaviour on the Patagonian toothfish fishery. ICES J. Mar. Sci. 72(5), 1587-1597. https://doi.org/10.1093/icesjms/fsu221

Hamer, D.J., Childerhouse, S.J., Gales, N.J., 2012. Odontocete bycatch and depredation in longline fisheries: A review of available literature and of potential solutions. Mar. Mammal Sci. 28(4), E345-E374. https://doi.org/10.1111/j.1748-7692.2011.00544.x

Hill, P.S., Laake, J.L., Mitchell, E.D., 1999. Results of a pilot program to document interactions between sperm whales and longline vessels in Alaskan waters. US Department of Commerce, National Oceanic and Atmospheric Administration, National Marine Fisheries Service, Alaska Fisheries Science Center.

Hucke-Gaete, R., Moreno, C.A., Arata, J., Ctr, B.W., 2004. Operational interactions of sperm whales and killer whales with the Patagonian toothfish industrial fishery off southern Chile. CCAMLR Sci. 11, 127-140.

https://203.13.22.3/ru/system/files/science_journal_papers/08huckegaete-etal.pdf 
Jaquet, N., 1996. How spatial and temporal scales influence understanding of sperm whale distribution: a review. Mammal Rev. 26(1), 51-65.

Jaquet, N., Dawson, S., Slooten, E., 2000. Seasonal distribution and diving behaviour of male sperm whales off Kaikoura: foraging implications. Can. J. Zool. 78, 407-419. https://doi.org/https://doi.org/10.1139/z99-208

Jaquet, N., Gendron, D., 2002. Distribution and relative abundance of sperm whales in relation to key environmental features, squid landings and the distribution of other cetacean species in the Gulf of California, Mexico. Mar. Biol. 141, 591-601. https://doi.org/10.1007/s00227-002-0839-0

Kaschner, K., Pauly, D., 2004. Competition between marine mammals and fisheries: Food for thought, p.95-117, in: D.J. Salem and A. N. Rowan, The state of Animals III. Humane society, Washington, D. C.

Kawakami, T., 1980. A review of sperm whale food. Sci Rep Whales Res Inst 32, 199-218. http://www.icrwhale.org/pdf/SC032199-218.pdf

Kock, K.-H., Purves, M.G., Duhamel, G., 2006. Interactions between cetacean and fisheries in the Southern Ocean. Polar Biol. 29, 379-388. https://doi.org/10.1007/s00300-005-0067-4

Labadie, G., Tixier, P., Barbraud, C., Fay, R., Gasco, N., Duhamel, G., Guinet, C., 2018. First demographic insights on historically harvested and poorly known male sperm whale populations off the Crozet and Kerguelen Islands (Southern Ocean). Mar. Mammal Sci. https://doi.org/10.1111/mms.12469

Løkkeborg, S., Bjordal, \AAsmund, 1992. Species and size selectivity in longline fishing: a review. Fish. Res. 13(3), 311-322.

http://www.sciencedirect.com/science/article/pii/0165783692900847

Maccarrone, V., Buffa, G., Di Stefano, V., Filiciotto, F., Mazzola, S., Buscaino, G., 2014. Economic assessment of dolphin depredation damages and pinger use in artisanal fisheries in the Archipelago of Egadi Islands (Sicily). Turk. J. Fish. Aquat. Sci. 14(1), 173-181. http://www.trjfas.org/pdf/issue_14_01/0119.pdf

Madsen, P.., Wahlberg, M., Møhl, B., 2002. Male sperm whale (Physeter macrocephalus) acoustics in a high-latitude habitat: implications for echolocation and communication. Behav. Ecol. Sociobiol. 53(1), 31-41. https://doi.org/10.1007/s00265-002-0548-1

[dataset] Martin, A., Pruvost, P., 2007. Pecheker, relational database for analysis and management of fisheries and related biological data from the French Southern Ocean fisheries monitoring scientific programs. Muséum National d'Histoire Naturelle.

Mellinger, D.K., Stafford, K.M., Fox, C.G., 2004. Seasonal occurrence of sperm whale (Physeter marcocephalus) sounds in the Gulf of Alaska 1999-2001. Mar. Mammal Sci. 20(1), 4862. https://doi.org/10.1111/j.1748-7692.2004.tb01140.x

Mesnick, S., Warner, N., Straley, J., O’Connell, V., Purves, M., Guinet, C., Dyb, J.-E., Lunsford, C., Roche, C., Gasco11, N., 2006. Global sperm whale (Physeter macrocephalus) depredation of demersal longlines, in: Symposium on fisheries depredation by killer and sperm whales: Behavioural insights, behavioural solutions.

http://www.vanaqua.org/depredation/Documents/MesnicketalFinalExtendedAbstract.kh.p df

Moir Clark, J., Agnew, D.J., 2010. Estimating the impact of depredation by killer whales and sperm whales on longline fishing for toothfish (Dissostichus eleginoides) around South Georgia. CCAMLR Sci. 17, 163-178.

https://www.ccamlr.org/fr/system/files/science_journal_papers/09moir-clark-andagnew.pdf 
Mooney, T.A., Pacini, A.F., Nachtigall, P.E., 2009. False killer whale (Pseudorca crassidens) echolocation and acoustic disruption: implications for longline bycatch and depredation. Can. J. Zool. 87(8), 726-733.

https://darchive.mblwhoilibrary.org/bitstream/handle/1912/3155/Mooney_etal_CJZ.pdf?s equence $=1$

Moreno, C.A., Castro, R., Mújica, L.J., Reyes, P., 2008. Significant conservation benefits obtained from the use of a new fishing gear in the Chilean Patagonian toothfish fishery. CCAMLR Sci. 15(1), 79-91. http://archive.ccamlr.org/ccamlr_science/Vol-152008/04moreno-et-al.pdf

Morissette, L., Christensen, V., Pauly, D., 2012. Marine mammal impacts in exploited ecosystems: Would large scale culling benefit fisheries? PLoS ONE 7(9). https://doi.org/10.1371/journal.pone.0043966

Muñoz-Lechuga, R., Rosa, D., Coelho, R., 2016. Depredation in the Portuguese pelagic longline fleet in the Indian Ocean. IOTC 12(35).

Nielsen, J.R., Thunberg, E., Holland, D.S., Schmidt, J.O., Fulton, E.A., Bastardie, F., Punt, A.E., Allen, I., Bartelings, H., Bertignac, M., Bethke, E., Bossier, S., Buckworth, R., Carpenter, G., Christensen, A., Christensen, V., Da-Rocha, J.M., Deng, R., Dichmont, C., Doering, R., Esteban, A., Fernandes, J.A., Frost, H., Garcia, D., Gasche, L., Gascuel, D., Gourguet, S., Groeneveld, R.A., Guillén, J., Guyader, O., Hamon, K.G., Hoff, A., Horbowy, J., Hutton, T., Lehuta, S., Little, L.R., Lleonart, J., Macher, C., Mackinson, S., Mahevas, S., Marchal, P., Mato-Amboage, R., Mapstone, B., Maynou, F., Merzéréaud, M., Palacz, A., Pascoe, S., Paulrud, A., Plaganyi, E., Prellezo, R., van Putten, E.I., Quaas, M., RavnJonsen, L., Sanchez, S., Simons, S., Thébaud, O., Tomczak, M.T., Ulrich, C., van Dijk, D., Vermard, Y., Voss, R., Waldo, S., 2018. Integrated ecological-economic fisheries models - Evaluation, review and challenges for implementation. Fish Fish. 19(1), 1-29. https://doi.org/10.1111/faf.12232

Nolan, C.P., Liddle, G.M., Elliot, J., 2000. Interactions between killer whales (Orcinus orca) and sperm whales (Physeter macrocephalus) with a longline fishing vessel. Mar. Mammal Sci. 16(3), 658-664. https://doi.org/10.1111/j.1748-7692.2000.tb00961.x

Northridge, S.P., 1991. An updated world review of interactions between marine mammals and fisheries. Food \& Agriculture Org.

O’Connell, V., Straley, J., Liddle, J., Wild, L., Behnken, L., Falvey, D., Thode, A., 2015. Testing a passive deterrent on longlines to reduce sperm whale depredation in the Gulf of Alaska. ICES J. Mar. Sci. J. Cons. 72(5), 1667-1672. https://doi.org/10.1093/icesjms/fsv014

Oro, D., Cam, E., Pradel, R., Martínez-Abraín, A., 2004. Influence of food availability on demography and local population dynamics in a long-lived seabird. Proc. R. Soc. Lond. B Biol. Sci. 271(1537), 387-396.

https://www.ncbi.nlm.nih.gov/pmc/articles/PMC1691609/pdf/15101698.pdf

Passadore, C., Domingo, A., Secchi, E.R., 2015. Depredation by killer whale (Orcinus orca) and false killer whale (Pseudorca crassidens) on the catch of the Uruguayan pelagic longline fishery in Southwestern Atlantic Ocean. ICES J. Mar. Sci. J. https://doi.org/10.1093/icesjms/fsu251

Péron, C., Welsford, D.C., Ziegler, P., Lamb, T.D., Gasco, N., Chazeau, C., Sinègre, R., Duhamel, G., 2016. Modelling spatial distribution of Patagonian toothfish through lifestages and sex and its implications for the fishery on the Kerguelen Plateau. Prog. Oceanogr. 141, 81-95. https://doi.org/10.1016/j.pocean.2015.12.003 
Peterson, M.J., Carothers, C., 2013. Whale interactions with Alaskan sablefish and Pacific halibut fisheries: Surveying fishermen perception, changing fishing practices and mitigation. Mar. Policy 42, 315-324. https://doi.org/10.1016/j.marpol.2013.04.001

Peterson, M.J., Mueter, F., Criddle, K., Haynie, A.C., 2014. Killer whale depredation and associated costs to Alaskan Sablefish, Pacific Halibut and Greenland Turbot longliners. PLoS ONE 9(2). https://doi.org/10.1371/journal.pone.0088906

Pinheiro, J., Bates, D., DebRoy, S., Sarkar, D., R Core Team, 2016. nlme: Linear and nonlinear mixed effects models, R package version 3.1-125.

Plagányi, É., Butterworth, D.S., 2002. Competition with fisheries. Anim Behav 63, 301-310. http://cetus.ucsd.edu/sio133/PDF/Competition\%20w\%20Fisheries\%202009\%20Ency\%20 MMs.pdf

Powell, J.R., Wells, R.S., 2011. Recreational fishing depredation and associated behaviors involving common bottlenose dolphins (Tursiops truncatus) in Sarasota Bay, Florida. Mar. Mammal Sci. 27(1), 111-129. https://doi.org/10.1111/j.1748-7692.2010.00401.x

Purves, M.G., Agnew, D.J., Balguerias, E., Moreno, C.A., Watkins, B., 2004. Killer whale (Orcinus orca) and sperm whale (Physeter macrocephalus) interactions with longline vessels in the Patagonian toothfish fishery at South Georgia, South Atlantic. CCAMLR Sci. 11, 111-126. http://203.13.22.3/ru/system/files/science_journal_papers/07purvesetal.pdf

R Core Team, 2015. R: A Language and Environment for Statistical Computing. R Foundation for Statistical Computing, Vienna, Austria. https://www.R-project.org/.

Rabearisoa, N., Bach, P., Tixier, P., Guinet, C., 2012. Pelagic longline fishing trials to shape a mitigation device of the depredation by toothed whales. J. Exp. Mar. Biol. Ecol. 432-433, 55-63. https://doi.org/10.1016/j.jembe.2012.07.004

Read, A.J., 2005. Bycatch and depredation. Mar. Mammal Res. Conserv.

Read, A.J., 2008. The looming crisis: interactions between marine mammals and fisheries. J. Mammal. 89(3), 541-548. https://doi.org/10.1644/07-MAMM-S-315R1.1

Roche, C., Guinet, C., Gasco, N., Duhamel, G., 2007. Marine mammals and demersal longline fishery interactions in Crozet and Kerguelen Exclusive Economic Zones: an assessment of depredation levels. CCAMLR Sci. 14, 67-82.

http://archive.ccamlr.org/ccamlr_science/Vol-14-2007/04roche-etal.pdf

Schakner, Z.A., Lunsford, C., Straley, J., Eguchi, T., Mesnick, S.L., 2014. Using models of social transmission to examine the spread of longline depredation behavior among sperm whales in the Gulf of Alaska. PLoS ONE 9(10). https://doi.org/10.1371/journal.pone.0109079

Sigler, M.F., Lunsford, C.R., Straley, J.M., Liddle, J.B., 2008. Sperm whale depredation of sablefish longline gear in the northeast Pacific Ocean. Mar. Mammal Sci. 24(1), 16-27. https://doi.org/10.1111/j.1748-7692.2007.00149.x

Söffker, M., Trathan, P., Clark, J., Collins, M.A., Belchier, M., Scott, R., 2015. The impact of predation by marine mammals on Patagonian toothfish longline fisheries. PLoS ONE 10(3). https://doi.org/10.1371/journal.pone.0118113

Straley, J., O'Connell, V., Behenken, L., Thode, A., Liddle, J., Mesnick, S., 2006. Sperm whale and longline fisheries interactions in the Eastern Gulf of Alaska, in: Symposium on fisheries depredation by killer and sperm whales: Behavioural insights, behavioural solutions. http://www.vanaqua.org/depredation/Abstracts/Jan\%20Straley.pdf

Straley, J., O’Connell, V., Liddle, J., Thode, A., Wild, L., Behnken, L., Falvey, D., Lunsford, C., 2015. Southeast Alaska Sperm Whale Avoidance Project (SEASWAP): a successful 
collaboration among scientists and industry to study depredation in Alaskan waters. ICES J. Mar. Sci. J. Cons. 72(5), 1598-1609. https://doi.org/10.1093/icesjms/fsv090

Taylor, B.L., Baird, R., Barlow, J., Dawson, S.M., Ford, J., Mead, J.., Notarbartolo di Sciara, G., Wade, P., Pitman, R.L., 2008. Physeter macrocephalus. The IUCN Red List of Threatened Species 2008. http://dx.doi.org/10.2305/IUCN.UK.2008.RLTS.T41755A10554884.en.

Teloni, V., Mark, J.P., Patrick, M.J.O., Peter, M.T., 2008. Shallow food for deep divers: Dynamic foraging behavior of male sperm whales in a high latitude habitat. J. Exp. Mar. Biol. Ecol. 354, 119-131. https://doi.org/10.1016/j.jembe.2007.10.010

Thode, A., Mathias, D., Straley, J., O’Connell, V., Behnken, L., Falvey, D., Wild, L., Calambokidis, J., Schorr, G., Andrews, R., Liddle, J., Lestenkof, P., 2015. Cues, creaks, and decoys: using passive acoustic monitoring as a tool for studying sperm whale depredation. ICES J. Mar. Sci. J. Cons. 72(5), 1621-1636. https://doi.org/10.1093/icesjms/fsv024

Tilney, R., Purves, M.G., 1999. The status of integrated fisheries monitoring in South Africa. http://www.fao.org/docrep/x3900e/x3900e08.htm

Tixier, P., Gasco, N., Duhamel, G., Viviant, M., Authier, M., Guinet, C., 2010. Interactions of Patagonian toothfish fisheries with killer and sperm whales in the Crozet islands Exclusive Economic Zone: an assessment of depredation levels and insights on possible mitigation strategies. CCAMLR Sci. 17, 179-195.

http://www.ccamlr.org/en/system/files/science_journal_papers/10tixier-et-al.pdf

Tixier, P., 2012. Déprédation par les orques (Orcinus orca) et les cachalots (Physeter macrocephalus) sur les palangriers à la légine australe dans la ZEE de l'archipel de Crozet. Thèse de Doctorat Université d'Aix Marseille II. 367 pp. http://www.cebc.cnrs.fr/Fthese/PUBLI/Tixier.pdf

Tixier, P., Authier, M., Gasco, N., Guinet, C., 2015a. Influence of artificial food provisioning from fisheries on killer whale reproductive output: Artificial food provisioning and killer whale reproduction. Anim. Conserv. 18(2), 207-218. https://doi.org/10.1111/acv.12161

Tixier, P., Gasco, N., Duhamel, G., Guinet, C., 2015b. Habituation to an acoustic harassment device (AHD) by killer whales depredating demersal longlines. ICES J. Mar. Sci. 72(5), 1673-1681. https://doi.org/10.1093/icesjms/fsu166

Tixier, P., Vacquie Garcia, J., Gasco, N., Duhamel, G., Guinet, C., 2015c. Mitigating killer whale depredation on demersal longline fisheries by changing fishing practices. ICES J. Mar. Sci. 72(5), 1610-1620. https://doi.org/10.1093/icesjms/fsu137

Tixier, P., Gasco, N., Duhamel, G., Guinet, C., 2016. Depredation of Patagonian toothfish (Dissostichus eleginoides) by two sympatrically occurring killer whale (Orcinus orca) ecotypes: Insights on the behavior of the rarely observed type D killer whales. Mar. Mammal Sci. https://doi.org/10.1111/mms.12307

Tixier, P., Barbraud, C., Pardo, D., Gasco, N., Duhamel, G., Guinet, C., 2017. Demographic consequences of fisheries interaction within a killer whale (Orcinus orca) population. Mar. Biol. 164(8). https://doi.org/10.1007/s00227-017-3195-9

Treves, A., Wallace, R.B., Naughton-Treves, L., Morales, A., 2006. Co-managing HumanWildlife Conflicts: A Review. Hum. Dimens. Wildl. 11, 383-396. https://doi.org/10.1080/10871200600984265

Trijoulet, V., 2016. Bioeconomic modelling of seal impacts on West of Scotland fisheries. Thesis University of Strathclyde. 
https://www.researchgate.net/publication/320735149_Bioeconomic_modelling_of_seal_i mpacts_on_West_of_Scotland_fisheries

Trijoulet, V., Dobby, H., Holmes, S.J., Cook, R.M., 2018. Bioeconomic modelling of grey seal predation impacts on the West of Scotland demersal fisheries. ICES J. Mar. Sci. https://doi.org/10.1093/icesjms/fsx235

Trites, A.W., Livingston, P.A., Vasconcellos, M.C., Mackinson, S., Springer, A.M., Pauly, D., 1999. Ecosystem considerations and the limitations of ecosystem models in fisheries management: insights from the Bering Sea. Ecosyst. Approaches Fish. Manag. Univ. Alsk. Sea Grant AK-SG-99-01 Fairbanks 609-635.

Venables, W.N., Ripley, B.D., 2002. Modern applied statistics with S, Fourth. ed. Springer, New York.

Visser, I.N., 2000. Killer whale (Orcinus orca) interactions with longline fisheries in New Zealand waters. Aquat. Mamm. 26(3), 241-252.

http://www.aquaticmammalsjournal.org/share/AquaticMammalsIssueArchives/2000/Aqu aticMammals_26-03/26-03_Visser.pdf

Ward, E.J., Holmes, E.E., Balcomb, K.C., 2009. Quantifying the effects of prey abundance on killer whale reproduction. J. Appl. Ecol. 46(3), 632-640. https://doi.org/10.1111/j.13652664.2009.01647.x

Watkins, W.A., Moore, K.E., Tyack, P., 1985. Sperm whale acoustic behaviors in the Southeast Caribbean. Cetology 19: 1-15.

Weimerskirch, H., Capdeville, D., Duhamel, G., 2000. Factors affecting the number and mortality of seabirds attending trawlers and long-liners in the Kerguelen area. Polar Biol. 23, 236-249.

https://www.researchgate.net/profile/Guy_Duhamel/publication/226970724_Factors_affe cting_the_number_and_mortality_of_seabirds_attending_trawlers_and_longliners_in_the_Kerguelen_area/links/Ofcfd5084ee8941663000000.pdf

Werner, T.B., Northridge, S., Press, K.M., Young, N., 2015. Mitigating bycatch and depredation of marine mammals in longline fisheries. ICES J. Mar. Sci. 72(5), 1576-1586. https://doi.org/10.1093/icesjms/fsv092

Whitehead, H., 2003. Sperm whales: Social evolution in the Ocean. University of Chicago Press.

Williams, R., Krkošek, M., Ashe, E., Branch, T.A., Clark, S., Hammond, P.S., Hoyt, E., Noren, D.P., Rosen, D., Winship, A., 2011. Competing conservation objectives for predators and prey: Estimating killer whale prey requirements for Chinook salmon. PLOS ONE 6(11). https://doi.org/10.1371/journal.pone.0026738

Woodroffe, R., Thirgood, S., Rabinowitz, A., 2005. People and wildlife, conflict or co-existence? Cambridge University Press.

Yates, O., Brickle, P., 2007. On the relative abundance and distribution of sperm whales (Physeter macrocephalus) and killer whales (Orcinus orca) in the Falkland Islands. J. $\begin{array}{llll}\text { Cetacean } & \text { Res. } & \text { 95-71. }\end{array}$ https://www.researchgate.net/profile/Oliver_Yates/publication/270158731_On_the_relati ve_abundance_and_distribution_of_sperm_whales_Physeter_macrocephalus_and_killer_ whales_Orcinus_orca_in_the_Falkland_Islands_longline_fishery/links/54a155320cf267b db902b531.pdf

Yukhov, V.N., 1972. The range of fish of the genus Dissostichus (fam. Nototheniidae) in Antarctic waters of the Indian Ocean. J. Ichthyol. 12(2), 346-347.

Yukhov, V.N., 1982. Antarkticheskii klykach. Nauka Mosc. 113 pp. (in Russian). 
Zuur, A., Ieno, E.N., Walker, N., Saveliev, A.A., Smith, G.M., 2009. Mixed effects models and extensions in Ecology with R. Springer Science \& Business Media.

Zuur, A.F., Ieno, E.N., Elphick, C.S., 2010. A protocol for data exploration to avoid common statistical problems: Data exploration. Methods Ecol. Evol. 1, 3-14. https://doi.org/10.1111/j.2041210X.2009.00001.x

Zuur, A.F., 2012. A beginner's guide to generalized additive models with R, 2nd print. ed. Highland Statistics Ltd, Newburgh, UK.

Zuur, A.F., Hilbe, J.M., Ieno, E.N., 2013. A beginner's Guide to GLM and GLMM with R: A frequentist and Bayesian perspective for ecologists. Highland Statistics, Newburgh UK. 


\section{Captions of figures}

2 Figure 1. Distribution of longline sets hauled in presence of depredating sperm whales (black dots) and

3 fishing grounds $\left(0.2^{\circ} \times 0.2^{\circ}\right.$ squares in which at least one set was hauled over the $2008-2015$ period -

4 grey squares) in Crozet (top) and in Kerguelen (bottom). Thin grey lines are the 500, 1000, 2000 and 4000

5 m isobaths.

8 Figure 2. Intra-annual variations of a. the number of sperm whale individuals depredating the same set 9 (mean \pm SD calculated from observed values) and $b$. the probability and confidence interval at $95 \%$ (error 10 bars) of sperm whale depredation to occur during hauling of sets as predicted by Model 1 outputs of the 11 month as a discrete predictor in Crozet (grey) and in Kerguelen (black). The mean proportions of sets 12 depredated by sperm whales per year over the study period (horizontal lines) are also depicted.

15 Figure 3. Predicted probabilities from Model 2 outputs of sperm whale depredation to occur during hauling of the second of two successively hauled sets against the interaction effect between the distance travelled by vessels between these two sets and the number of sperm whales depredating on the first set in Crozet (a) and in Kerguelen (b). Each curve corresponds to a given number of sperm whales simultaneously depredating the first set, ranging from 0 (light grey) to 8 (dark grey).

22 Figure 4. Boxplots of observed CPUE values per longline set for Patagonian toothfish (top) and for the 23 bycatch species groups (Antimora, Grenadier and Skate, bottom) when sets were hauled without 24 depredation (absence of any odontocete species confirmed - light grey) and with confirmed depredation by 25 sperm whales as the only depredating species (black) in Crozet (left) and in Kerguelen (right). Points are 
26 the outliers of the boxplots. *** indicate a significant difference $(P<0.001)$ in CPUE values between sets

27 hauled in absence and in presence of sperm whales (Student t-test comparisons).

30 Figure 5. Predicted estimates from Model 3 outputs of the interaction effect between the soaking time of 31 longline sets and the number of sperm whales depredating the same set on the Patagonian toothfish CPUE

32 in Crozet. Each curve corresponds to a given number of sperm whales depredating the same set, ranging 33 from 0 (light grey) to 5 (dark grey).

36 Figure 6. Predicted estimates from Model 3 outputs of the interaction effect between the hauling speed of 37 longline sets and the number of sperm whales depredating the same set on the Patagonian toothfish CPUE 38 in Kerguelen. Each curve corresponds to a given number of sperm whales depredating the same set, 39 ranging from 0 (light grey) to 4 (dark grey). 

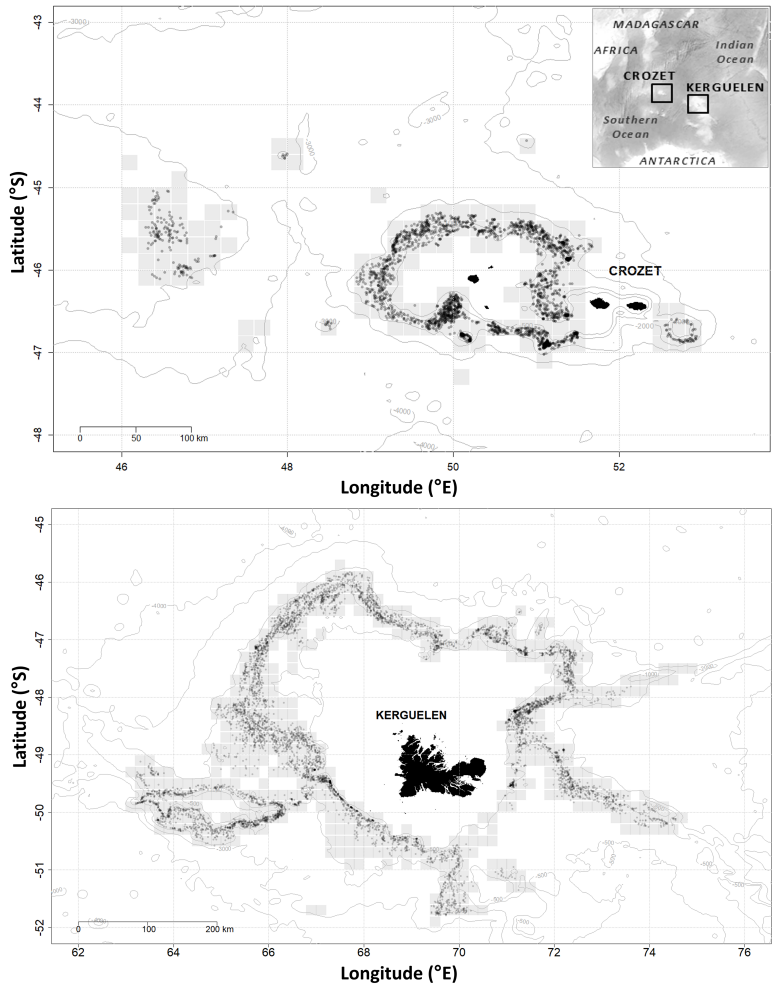
a.

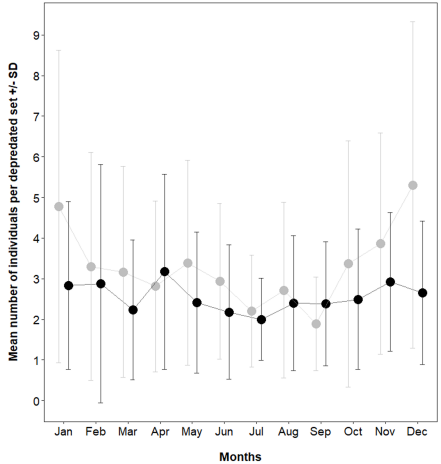

- Crozet

- Kerguelen

b.

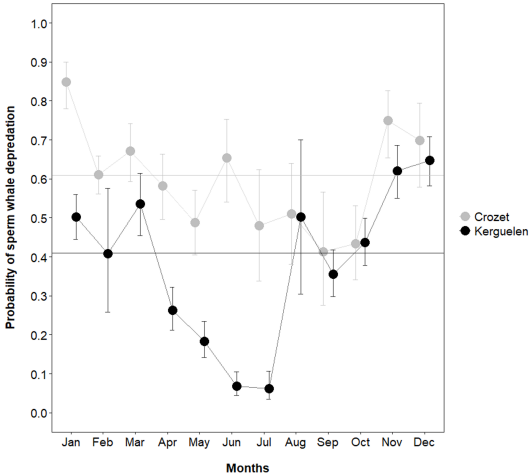



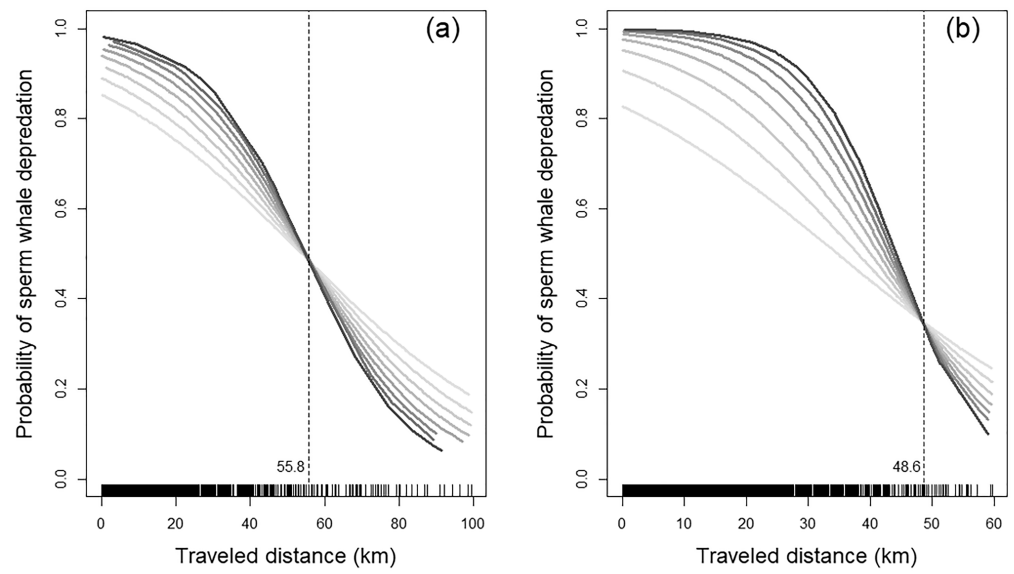
Crozet
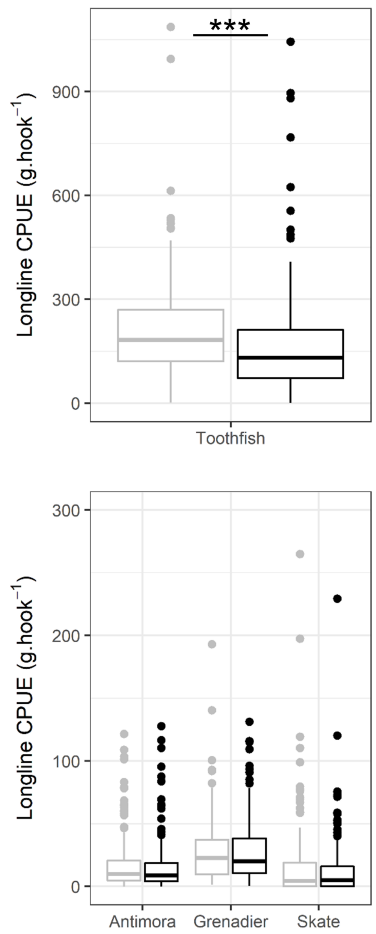

Kerguelen
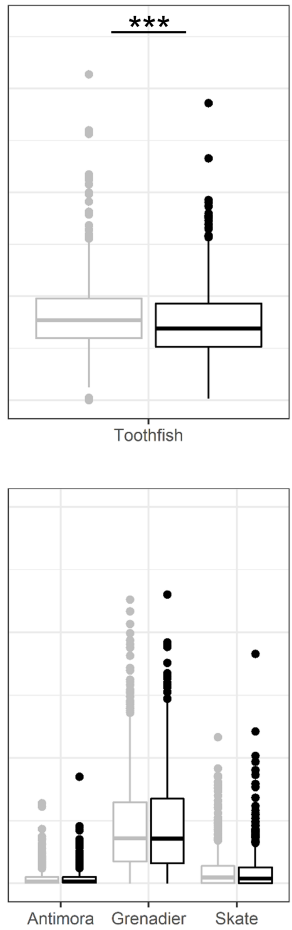

Absence Presence
Absence Presence 


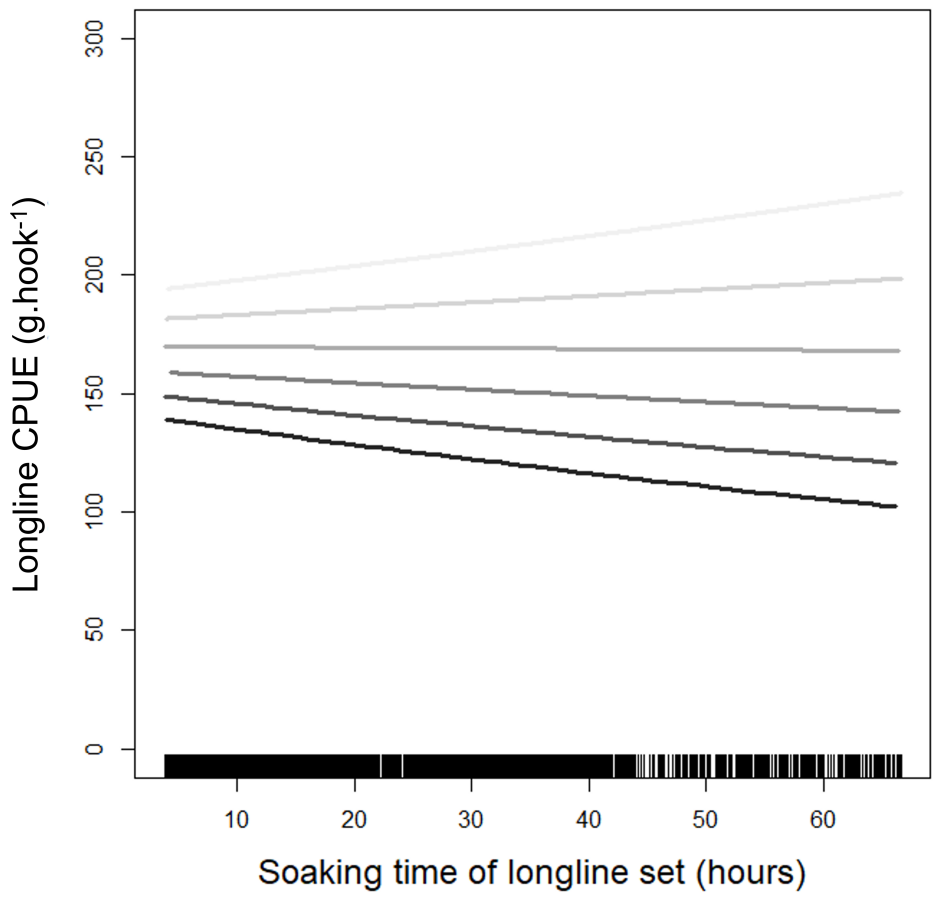




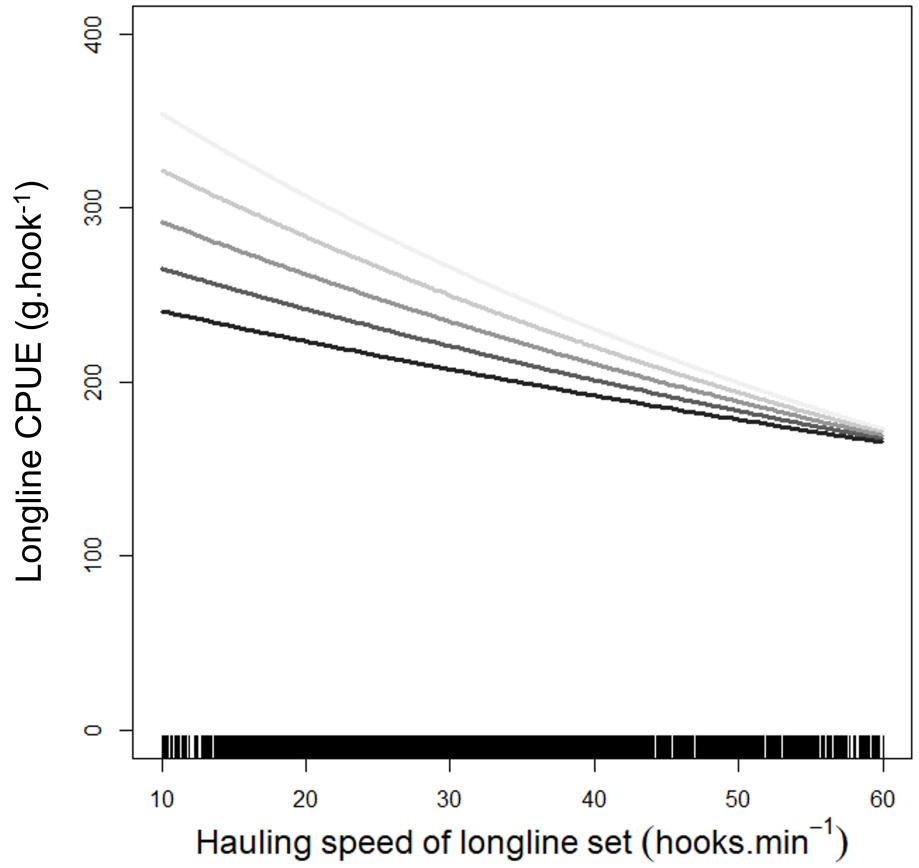




\section{Tables}

Table 1. Numerical outputs from Model 1 testing the effects of the year (Year) and the depth (Depth) at which longline sets were hauled as continuous standardized predictors, as well as the effect of the month (Month) as discrete predictor on the proportion of sets depredated by sperm whales out of all sets hauled in Crozet and in Kerguelen. The baseline is represented by the month having the lowest probability of interaction and is the level with which the estimated probabilities of sets to be depredated of the other months are compared. The fishing trip (Trip) was added as a random term in Model 1 along with an autocorrelation structure AR1 within each Trip.

\begin{tabular}{|c|c|c|c|c|c|c|c|c|c|c|}
\hline & \multicolumn{5}{|c|}{ CROZET $(N=5217$ sets $)$} & \multicolumn{5}{|c|}{ KERGUELEN $(N=16738$ sets $)$} \\
\hline & Value & $S E$ & $d f$ & $t$ & $P$ & Value & $S E$ & $d f$ & $t$ & $P$ \\
\hline Intercept & -0.35 & 0.32 & 5094 & -1.11 & 0.27 & -2.74 & 0.31 & 16559 & -8.86 & 0.00 \\
\hline Year & - & - & - & - & NS & - & - & - & - & NS \\
\hline January & 2.09 & 0.39 & 5094 & 5.30 & 0.00 & 2.76 & 0.33 & 16559 & 8.37 & 0.00 \\
\hline February & 0.81 & 0.33 & 5094 & 2.45 & 0.01 & 2.28 & 0.46 & 16559 & 4.91 & 0.00 \\
\hline March & 1.07 & 0.36 & 5094 & 2.99 & 0.003 & 2.89 & 0.35 & 16559 & 8.38 & 0.00 \\
\hline April & 0.69 & 0.36 & 5094 & 1.91 & 0.06 & 1.74 & 0.33 & 16559 & 5.24 & 0.00 \\
\hline May & 0.33 & 0.36 & 5094 & 0.92 & 0.36 & 1.24 & 0.32 & 16559 & 3.86 & $<0.001$ \\
\hline June & 1.00 & 0.40 & 5094 & 2.51 & 0.01 & 0.10 & 0.32 & 16559 & 0.30 & 0.76 \\
\hline July & 0.28 & 0.44 & 5094 & 0.65 & 0.51 & Baseline & Baseline & Baseline & Baseline & Baseline \\
\hline August & 0.39 & 0.41 & 5094 & 0.95 & 0.34 & 2.79 & 0.47 & 16559 & 5.91 & 0.00 \\
\hline September & Baseline & Baseline & Baseline & Baseline & Baseline & 2.11 & 0.34 & 16559 & 6.28 & 0.00 \\
\hline October & 0.10 & 0.37 & 5094 & 0.28 & 0.78 & 2.48 & 0.33 & 16559 & 7.41 & 0.00 \\
\hline November & 1.44 & 0.39 & 5094 & 3.71 & $<0.001$ & 3.23 & 0.34 & 16559 & 9.41 & 0.00 \\
\hline December & 1.19 & 0.41 & 5094 & 2.88 & 0.004 & 3.36 & 0.34 & 16559 & 9.90 & 0.00 \\
\hline Depth & - & - & - & - & NS & 0.18 & 0.02 & 16559 & 7.94 & 0.00 \\
\hline & $\mathrm{Au}$ & $\begin{array}{r}\text { Rand } \\
\text { Resid } \\
\text {-correlatic }\end{array}$ & $\begin{array}{l}\mathrm{m} \text { intercept } \\
\text { lal variance } \\
\text { a parameter }\end{array}$ & $\begin{array}{l}0.51 \\
0.98 \\
\text { estimate : }\end{array}$ & .36 & Aut & $\begin{array}{r}\text { Rand } \\
\text { Resid } \\
\text {-correlatic }\end{array}$ & $\begin{array}{l}\mathrm{n} \text { intercep } \\
\text { al variance } \\
\text { paramete }\end{array}$ & $\begin{array}{l}0.77 \\
0.96 \\
\text { estimate : }\end{array}$ & .51 \\
\hline
\end{tabular}


Table 2. Numerical outputs from Model 2 testing the effects of the distance travelled by fishing vessels between two successively hauled sets (Distance) and the number of sperm whales recorded depredating during the hauling of the first of these two sets $\left(\mathrm{Nb}\right.$.ind.set $\left._{-1}\right)$ as continuous standardized predictors on the proportion of next sets depredated by sperm whales. The fishing trip (Trip) was entered in Model 2 as a random term.

\begin{tabular}{|c|c|c|c|c|c|c|c|c|}
\hline & \multicolumn{4}{|c|}{ CROZET $(N=1180$ sets $)$} & \multicolumn{4}{|c|}{ KERGUELEN $(N=4223$ sets $)$} \\
\hline & Estimate & $S E$ & $z$ & $P$ & Estimate & $S E$ & $z$ & $P$ \\
\hline Intercept & 1.65 & 0.11 & 14.70 & $<0.001$ & 1.91 & 0.10 & 19.74 & $<0.001$ \\
\hline Nb.ind.set $_{-1}$ & 0.42 & 0.10 & 4.04 & $<0.001$ & 0.90 & 0.07 & 12.18 & $<0.001$ \\
\hline Distance & -0.76 & 0.08 & -9.62 & $<0.001$ & -0.66 & 0.04 & -14.74 & $<0.001$ \\
\hline \multirow[t]{2}{*}{ Distance:Nb.ind.set $t_{-1}$} & -0.19 & 0.08 & -2.40 & 0.02 & -0.24 & 0.04 & -5.26 & $<0.001$ \\
\hline & \multicolumn{4}{|c|}{ Random intercept : 0.28} & \multicolumn{4}{|c|}{ Random intercept : 0.77} \\
\hline
\end{tabular}


Table 3. Numerical outputs from Model 3 testing the effects of the number of sperm whales simultaneously depredating the same set $(N b$.ind), the length of longline sets (Length), the soaking time (SoakingTime), the speed (HaulingSpeed) and the depth (Depth) at which sets were hauled as continuous standardized predictors on the Patagonian toothfish CPUE. The fishing trip (Trip) was entered in Model 3 as a random term.

\begin{tabular}{|c|c|c|c|c|c|c|c|c|}
\hline & \multicolumn{4}{|c|}{ CROZET $(N=2695$ sets $)$} & \multicolumn{4}{|c|}{ KERGUELEN $(N=15080$ sets $)$} \\
\hline & Estimate & $S E$ & $t$ & $P$ & Estimate & $S E$ & $t$ & $P$ \\
\hline Intercept & 5.20 & 0.05 & 97.39 & $<0.001$ & 5.49 & 0.02 & 305.25 & $<0.001$ \\
\hline Nb.ind & -0.15 & 0.02 & -8.56 & $<0.001$ & -0.07 & 0.005 & -14.09 & $<0.001$ \\
\hline Length & -0.14 & 0.02 & -6.30 & $<0.001$ & -0.08 & 0.005 & -16.63 & $<0.001$ \\
\hline Depth & -0.06 & 0.02 & -2.78 & 0.005 & - & - & - & NS \\
\hline SoakingTime & 0.02 & 0.02 & 0.91 & 0.36 & 0.05 & 0.005 & 9.83 & $<0.001$ \\
\hline HaulingSpeed & -0.09 & 0.02 & -3.74 & $<0.001$ & -0.10 & 0.006 & -16.16 & $<0.001$ \\
\hline Length:Nb.ind & - & - & - & NS & - & - & - & NS \\
\hline Depth:Nb.ind & - & - & - & NS & - & - & - & NS \\
\hline SoakingTime:Nb.ind & -0.03 & 0.02 & -1.97 & 0.05 & - & - & - & NS \\
\hline HaulingSpeed:Nb.ind & - & - & - & NS & 0.02 & 0.004 & 3.54 & $<0.001$ \\
\hline & \multicolumn{4}{|c|}{ Random intercept : 0.15} & \multicolumn{4}{|c|}{$\begin{array}{l}\text { Random intercept : } 0.02 \\
\text { Residual variance : } 0.25\end{array}$} \\
\hline
\end{tabular}


Supplementary Data

Calculations of CPUE losses per depredating sperm whale individual

April 9 $9^{\text {th }}, 2018$ 


\section{Supplementary Data for:}

How do fishing practices influence sperm whale (Physeter macrocephalus) depredation on demersal longline fisheries?

Anaïs Janc ${ }^{1 *}$, Gaëtan Richard ${ }^{1,2,3}$, Christophe Guinet ${ }^{1}$, John P.Y. Arnould ${ }^{3}$, Maria Ching Villanueva ${ }^{4}$, Guy Duhamel ${ }^{5}$, Nicolas Gasco ${ }^{5}$ and Paul Tixier ${ }^{3}$

${ }^{1}$ Centre d'Études Biologiques de Chizé (CEBC), UMR 7273 - CNRS and Université de La Rochelle, 79360 Villiers-en-Bois, France

${ }^{2}$ Lab-STICC UMR 6285, ENSTA Bretagne, 2 rue François Verny, 29806 Brest Cedex 9, France

${ }^{3}$ School of Life and Environmental Sciences (Burwood Campus), Deakin University, 221 Burwood Highway, Burwood, VIC 3125, Australia

${ }^{4}$ Laboratoire de Biologie Halieutique (STH-LBH), IFREMER, ZI de la Pointe du Diable, BP 70, 29280 Plouzané, France

${ }^{5}$ Muséum National d'Histoire Naturelle, Département Adaptations du Vivant, UMR 7208 BOREA, CP 26, 43 rue Cuvier, 75005 Paris, France

*Corresponding author: anais.janc@cebc.cnrs.fr

Gaëtan Richard: gaetan.richard@cebc.cnrs.fr

Christophe Guinet: christophe.guinet@cebc.cnrs.fr

John P.Y. Arnould: john.arnould@ deakin.edu.au

Maria Ching Villanueva: ching.villanueva@ifremer.fr

Guy Duhamel: guy.duhamel@mnhn.fr

Nicolas Gasco: nicolas.gasco@mnhn.fr

Paul Tixier: p.tixier@deakin.edu.au 
Method in details on the way estimations of CPUE loss per sperm whale individual were calculated from mathematical equation of Model 3 and model estimates provided in Table 3.

$\log (\overline{C P U E})=$ Intercept $+\beta_{1}$ Nb.ind $+\beta_{2}$ Length $+\beta_{3}$ Depth $+\beta_{4}$ SoakingTime $+\beta_{5}$ HaulingSpeed $+\beta_{6}$ Length $\times$ Nb.ind $+\beta_{7}$ Depthx Nb.ind $+\beta_{8}$ SoakingTime $\times$ Nb.ind $+\beta_{9}$ HaulingSpeed $\mathrm{x}$ Nb.ind

in all the continuous explanatory predictors except $N b$.ind were set to zero because they were standardized (i.e., they were centered at their mean and scaled by their standard deviation) in the model and here, assumed to be on their averages. As a result, the mean CPUE $(\overline{C P U E})$ was calculated as follows:

$\leftrightarrow \log (\overline{C P U E})=$ Intercept $+\beta_{1}$ Nb.ind

$\leftrightarrow \overline{C P U E}=\exp \left(\right.$ Intercept $+\beta_{1}$ Nb.ind $)$.

When there was no sperm whale depredation:

$\overline{C P U E}_{\text {abs. }}=\exp ($ Intercept $+\beta 1$ Nb.ind $)$ in which Nb.ind was centered at its mean (2.23 and 2.03 for Crozet and Kerguelen, respectively) and scaled by its standard deviation (1.26 and 1.03 for Crozet and Kerguelen, respectively) and was therefore equal to -1.77 (i.e., (0-2.23)/1.26) and -1.97 (i.e., (0-2.03)/1.03) for Crozet and Kerguelen, respectively.

When there was sperm whale depredation and based on an average number of sperm whales depredating on the same set, $N b$.ind was therefore zero because it was standardized:

$\overline{C P U E}_{\text {depred. }}=\exp ($ Intercept $)$.

The CPUE loss per sperm whale individual was calculated as follows:

$\overline{C P U E}_{\text {loss per ind. }}=\left(\overline{C P U E}_{\text {abs. }}-\overline{C P U E}_{\text {depred. }}\right) / 2.23$ at Crozet

$\overline{C P U E}_{\text {loss per ind. }}=\left(\overline{C P U E}_{\text {abs. }}-\overline{C P U E}_{\text {depred. }}\right) / 2.03$ at Kerguelen. 